\title{
Bioreactors with immobilized lipases: State of the art
}

\author{
Victor M. Balcão, Ana L. Paiva and F. Xavier Malcata \\ Escola Superior de Biotecnologia, Universidade Católica Portuguesa, Porto, Portugal
}

\begin{abstract}
This review attempts to provide an updated compilation of studies reported in the literature pertaining to reactors containing lipases in immobilized forms, in a way that helps the reader direct a bibliographic search and develop an integrated perspective of the subject. Highlights are given to industrial applications of lipases (including control and economic considerations), as well as to methods of immobilization and configurations of reactors in which lipases are used. Features associated with immobilized lipase kinetics such as enzyme activities, adsorption properties, optimum operating conditions, and estimates of the lumped parameters in classical kinetic formulations (Michaelis-Menten model for enzyme action and first-order model for enzyme decay) are presented in the text in a systematic tabular form.
\end{abstract}

Keywords: Immobilized lipases; activity; stability; optimum operating conditions; reactors

\section{Characteristics and applications of lipases}

Lipases, also known as glycerol ester hydrolases (EC 3.1.1.3), belong to the hydrolase enzyme class and were originally employed for the hydrolysis of ester bonds. In addition to plants and animals, in which these enzymes are widespread, many microorganisms (natural or genetically engineered) are also capable of actively producing these cnzymes both in endogenous and exogenous forms.

Lipases are unique enzymes in that they require interfacial activation for full catalytic performance, a fact that was initially established in 1958 by Sarda and Desnuelle. ${ }^{1}$ (An interface is hereby considered as the imaginary surface that separates two physically distinct phases, which corresponds on the molecular level to a set of two adjacent layers of ordered molecules, one more hydrophobic and the other more hydrophilic in nature.) Although several theories have been postulated to explain the observed enhancement of lipase activity upon formation of an interface, ${ }^{2}$ recent reports evolving from paneuropean projects on lipases sponsored by the BRIDGE (EC) and the Nordic (Scandinavian) protein engineering programs have shed, in a dramatic fash-

Address reprint requests to Dr. Malcata, Escola Superior de Biotecnologia, Rua Dr. António Bernardino de Almeida, 4200 Porto, Portugal ion, experimental light over such theoretical interpretations via determination of the three-dimensional structure of 10 lipases and characterization of the kinetic behavior and stereoselectivity of 25 different lipases. It is now well established that: 1) all lipases share primary sequence homologies including significant regions His- $X-Y$-Gly-Z-Ser- $W$ Gly or $Y$-Gly-His-Ser-W-Gly (where $X, Y, Z$, and $W$ denote generic amino acid residues) ${ }^{3}$; and 2 ) the serine residue at the active site is protected by a flap (or $\alpha$-helical lid), which opens upon contact of the lipase with an interface and thus leads to restructuring of the lipase by creating an electrophilic region (the oxyanion hole) around the aforementioned serine residue, by exposing hydrophobic residues, and by burying hydrophilic ones, all of which increase the affinity of the complex for lipid substrates and help stabilize the transition state intermediate during catalysis. ${ }^{46}$ The requirement for an interface (irrespective of its nature) is critical; even if one uses a hydrophobic solvent, there are small local pools of water remaining within the folded structure of the lipase, and those water pools in the vicinity of the active site may provide the local interface necessary for enzyme activation.

Lipases catalyze a series of different reactions. In fact, although they were designed by nature to cleave ester bonds of triacylglycerols with the concomitant consumption of water molecules (hydrolysis), lipases are also able to catalyze the reverse reaction under microaqueous conditions, 
viz. the formation of ester bonds between alcohol and carboxylic acid moieties (ester synthesis). These two basic processes can then be combined in a sequential fashion to give rise to a set of reactions generally termed interesterifications. Depending on the particular starting point in terms of substrates, one may have acidolysis (where an acyl moiety is displaced betwcen an acylglycerol and a carboxylic acid), alcoholysis (where an acyl moiety is displaced between an acylglycerol and an alcohol), and transesterification (where two acyl moieties are exchanged between two acylglycerols). All these processes are depicted in Figure 1.

Although lipase-catalyzed reactions can also be carried out using inorganic, metal-derived catalysts, the interest generated by these enzymes as biotechnological vectors for the achievement of various types of reactions in both macroand microaqueous systems has expanded formidably during the last decade. Indeed, lipase-catalyzed reactions resemble closely the pathways designed by nature for the metabolism of live beings, and so the reaction mechanisms and processes associated therewith may be viewed as more environment friendly than bulk syntheses. Furthermore, lipases are capable of producing a wide variety of products with potential high purity (and consequently high added value) resulting from their substrate specificity and stereospecificity. Because of the low activation energies involved, further advantages of lipases include mild reaction conditions of temperature and $\mathrm{pH}$, which lead to reduced energy consumption and less extensive thermal damage to reactants and products.

Although technical staff are well aware of their versatility and possible applications in industry, the use of lipases is not yet as significant as that associated with such other enzymes as proteases and carbohydrases. This may be because of, first, most detailed studies involving lipases are recent and the usual time lag prior to full commercial exploitation has not yet elapsed, and, second, their cost is still

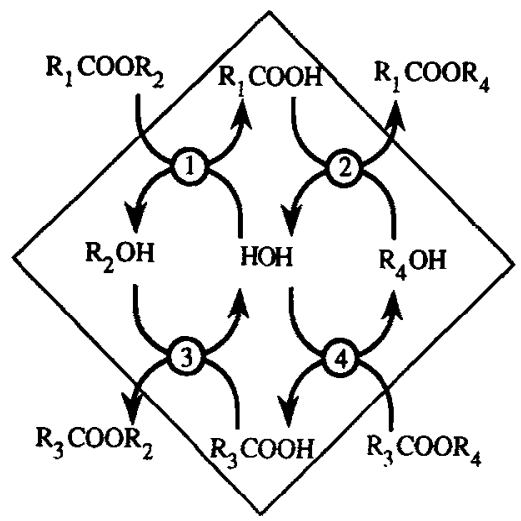

$1:$ Hydrolysis

2 : Ester synthesis

$1+2$ : Alcoholysis

$1+3:$ Acidolysis

$1+2+3+4:$ Transesterification

Figure 1 Schematic representation of the reactions catalyzed by lipases, where $R_{i}(i=1,2,3,4)$ denotes an acyl moiety relatively high, a constraint that will eventually be overcome in the coming years as a result of evolution encompassing their extraction and purification, as well as their production via genetic engineering.

The manufacture of household detergents remains the biggest market for industrial enzymes in general, but only now is this market opening up for lipases after genetic design aiming at sufficient high stability and activity under the alkaline conditions prevailing in washing processes. Currently, one of the major application of lipases is in the dairy industry for the controlled hydrolysis of milk fat, a process which is useful for acceleration of cheese ripening, flavor enhancement of butter, manufacture of cheeselike products, and preparation of enzyme-modified cheeses for use as ingredients in dressings, soups, and sauces.

I.ipases possess high potential for hydrolysis, glycerolysis, and alcoholysis of bulk fats and oils because of their high specificity and the relative purity of the products derived therefrom. The use of such enzymes avoids the need for the high temperatures required by nonenzymatic splitting, which leads to thermal degradation of the products (e.g., generation of off-flavors and off-colors) and so to the need for postprocessing purification and refining. The upgrading of fats by specific syntheses and the randomization of structured triglycerides is also possible by the use of appropriate lipases, thus allowing the tailoring of fats for desired functional and nutritional properties. Another application pertains to the production of w3-polyunsaturated fatty acid ( $\omega 3$-PUFA) concentrates from fish liver oils (which have been claimed to provide beneficial health effects via prevention of coronary heart diseases) for use as nutropharmaceutical food supplements, and sequential lipase-catalyzed chemical incorporation in triglycerides.

Another industrial application with a promising future is the lipase-mediated production of optically pure compounds (rather than racemic mixtures) for pharmaceutical and finechemical uses. Lipase-catalyzed resolution of racemic aqueous mixtures can occur through asymmetric hydrolysis of the corresponding esters, whereas in nonaqueous media, this approach can be extended to stereo- and regiospecific (trans)esterification reactions. The synthesis of optically active polymers can also be accomplished by this route.

Further applications of lipases in industry include (but are not limited to) the production of emulsifiers for personal care products (skin and suntan creams and bath oils), esters of fatty acids and fatty alcohols (wax esters), and oil waste treatment.

\section{Immobilization of lipases}

Lipases are spontaneously soluble in aqueous solutions (as a result of their globular protein nature), but their natural substrates (i.e., lipids) are not. Although use of a proper organic solvent or an emulsifier helps overcoming the problem of intimate contact between substrate and enzyme, the practical use of lipases in such pseudohomogeneous reaction systems poses technological difficulties (viz. contamination of the products with residual enzymatic activity) and economic difficulties (viz. use of the enzyme for a single 
reactor pass). The former leads to constraints on the product level, because the final characteristics of the product depend on such postprocessing conditions as storage time and temperature. The latter leads to constraints on the process level, because the useful life of the enzyme is restricted to the space time of the reactor (on the assumption that the space time is small compared with the time scale associated with deactivation of the enzyme). In both cases, part of the overall potential enzymatic activity is lost. If the lipase is immobilized, then it becomes an independent phase within the reaction system, which may be easily retained in the reactor via mechanical means with concomitant advantages in preventing contamination of the products and extending its useful active life.

Immobilized lipases are considered hereafter as lipases which are localized in a defined region of space, which is enclosed by an imaginary or material barrier which allows for physical separation of the enzyme from the bulk reaction medium, and which is at the same time permeable to reactant and product molecules. Rending a lipase immobilized may therefore be achieved by engineering the enzyme microenvironment or macroenvironment. Examples of engineering on the level of the microenvironment of the enzyme encompass immobilization by attachment to a carrier (e.g., covalent attachment, hydrophobic and ion exchange adsorption, and cross-linking) and immobilization by containment in a barrier (e.g., microencapsulation using lipid vesicles, containment in reversed micelles, entrapment in polymeric matrices, and confinement in ultrafiltration hollow fibers). Engineering on the level of the macroenvironment of the enzyme may proceed via modification of the reaction medium (e.g., precipitation in an organic solvent).

In addition to the lipase, immobilization also requires an immobilizing agent (i.e., a force that keeps the enzyme as a separate phase from the bulk reaction medium). Such a force can be established between two enzyme molecules, E-E (e.g., cross-linking, intermolecular cystein and/or salt bridges, and intermolecular hydrogen bonds), or between one enzyme molecule and another catalytically inert molecule, E-C (e.g., covalent attachment, ion exchange, and hydrophobic interaction), or between two catalytically inert molecules, C-C (e.g., entrapment and mechanical containment). Virtually every immobilization protocol employed to date for lipases encompasses immobilizing agent(s) at one, two, or all three levels of interaction considered (i.e., E-E, $\mathrm{E}-\mathrm{C}$, and $\mathrm{C}-\mathrm{C}$, respectively). The immobilizing agent thus comprises: 1) covalent forces as in covalent attachment, cross-linking, entrapment via polymerization, containment within porous membranes of polymeric nature, and intermolecular cysteine bridges during precipitation; 2) ionic forces as in ion exchange, containment within porous membranes of mineral nature, and intermolecular salt bridges during precipitation in apolar solvents; 3 ) hydrogen bonds as in intermolecular interaction between hydrogen atoms and electronegative atoms during precipitation in apolar solvents; and 4) van der Waals forces as in hydrophobic adsorption, reversed micelles, microencapsulation, containment within porous membranes of monomeric and hydrophobic nature, and precipitation in polar solvents. The immobilizing agent may also include a material ligand; this is the case of multifunctional molecules in cross-linking and spacer molecules in covalent attachment following preliminary derivatization of the support.

The carrier (or the barrier) is an entity larger in size than the enzyme molecule (which may therefore be considered as a continuum) to which the enzyme is directly bound or within which the enzyme is confined, and has the role of helping in the creation of an immobilized, enzyme-rich phase. This support is absent in the case of cross-linking and plain precipitation of the enzyme in an organic solvent. The support may be a liquid, as in reversed micelles, or a solid, as in most of the commonly employed immobilization protocols.

When carriers (with lipase attached to them) or barriers (with lipase confined to them) are used to immobilize a lipase, considerations on three levels of structure are in the order: macroscopic level, microscopic level, and submicroscopic level. At the macroscopic level, there may be one dominant dimension (e.g., the length in the case of hollow fibers), two dominant dimensions (e.g., the surface in the case of flat-sheet membranes), or three dominant dimensions (e.g., the volume in the case of beads or dried micellia). The dominant dimension(s) are determined by the manufacture process and are directly related to the characteristics of the flow within the reactor (see below). In terms of microscopic characteristics, two factors are of relevance for solid supports: the thickness, on the one hand, and the

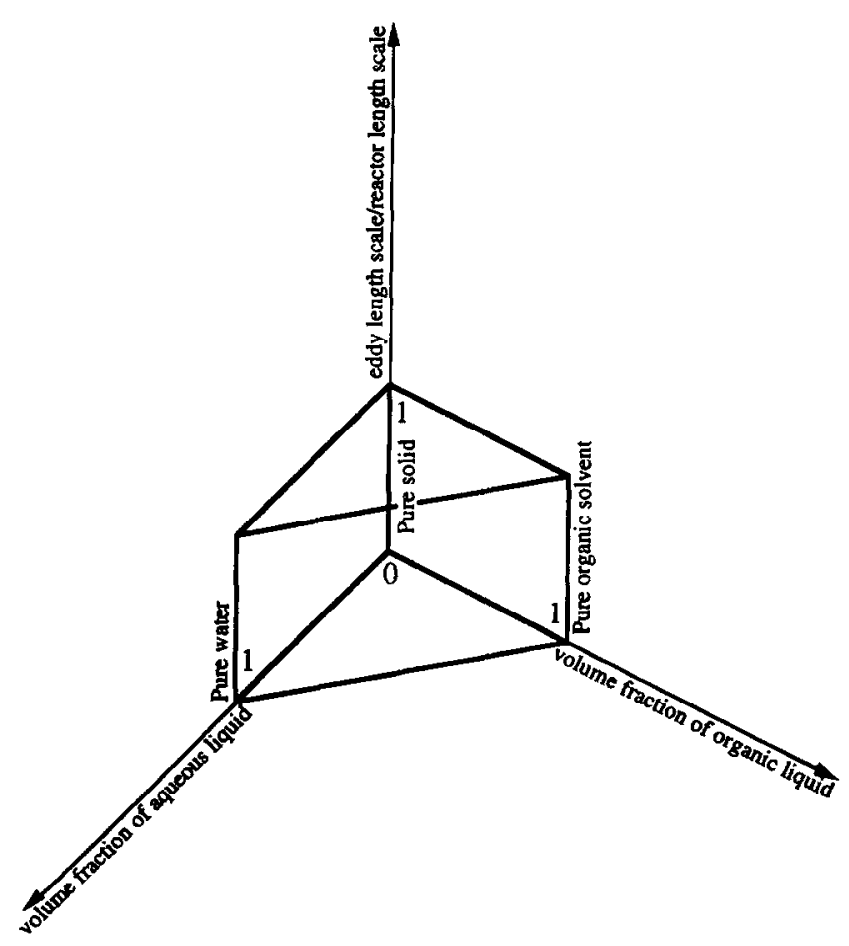

Figure 2 Immobilized lipase reactor pyramid enclosing the reactor configurations studied to date. The reactor space is characterized by an axis describing the ratio of length scales of the hydrodynamic eddies and the reactor itself, and two axes describing the volume fraction of the liquids in the reaction medium. The vertical sides of the pyramid correspond to a pure phase 
porous structure, on the other. Small thicknesses and high porosities are usually sought to minimize diffusional limitations upon substrates and maximize available area for lipase attachment, but they also lead to mechanical weakness; hence, a compromise must be reached. The submicroscopic character is a direct result of the molecular characteristics of the carrier and may range from hydrophilic (i.e., essentially polar) to hydrophobic (i.e., essentially nonpolar). In the case of hydrophobic carriers, the immobilized enzyme is soaked in the organic liquid phase, whereas in hydrophilic carriers the immobilized enzyme is soaked in water; the former situation is useful if one wants deactivation reactions of the enzyme to be maintained as slow as possible, whereas the latter situation should be used when hydrolysis reactions are desired.

An overview of the various reactor configurations employing immobilized lipases in the light of the framework introduced above will be presented in the next section. Later, the characteristic physicochemical features of such reactors (activity, stability, and optimum operating conditions) will be listed whenever available followed by control and economic considerations.

\section{Reactors with immobilized lipases}

An immobilized lipase reactor, which, as previously explained, is a more cost-effective reactional alternative than a soluble lipase reactor, may be viewed as a portion of space in which the lipase macroscopic movement is restricted to its boundaries. Therefore, the ratio of the length scale associated with the hydrodynamic eddies of the reaction medium to the length scale associated with the reactor may range from zero (a situation that corresponds to pure molecular transport of the reacting species between the reaction medium and the enzyme) to unity (a situation that corresponds to pure, long-range convection of the reacting molecules through the reactor). This concept is illustrated in Figure 2.

Generation of hydrodynamic eddies may result solely from Brownian motion (as in reactors operated batchwise under virtually stagnant conditions), or from some extent of mechanical input to the reacting system via shaft work (as in solid rotational agitators) or via non-shaft work (as in bubbling of a gas within the liquid system or in deliberately disturbing the liquid stream-line pattern following the motionless mixer principle as in reactors operated continuously under essentially turbulent conditions). In general, contact of the reactants with the immobilized lipase is improved by convection relative to plain molecular transport; however, convection is also associated with higher shear rates and/or higher times of exposure to shear (in the case of rotational or motionless agitation), or with higher surface tension and/ or higher interfacial areas (in the case of bubbling agitation), both of which promote disturbances of the elaborate threedimensional shape of the lipase molecules that lead to faster deactivation.

Confinement of the lipase to a given portion of space within the reacting fluid defined by imaginary boundaries requires either an electromagnetic or a gravitational field able to function as a barrier to the movement of the enzyme molecules and unable to significantly affect the movement of the reacting molecules. Both configurations have, however, been seldom reported to date for the case of lipase reactors.

The other (more frequent) situation consists in the confinement of the lipase to a given portion of space within the reacting fluid defined by physical boundaries coinciding with interfaces; such a configuration requires the existence of at least two phases which are separable by such purely mechanical means as settling, centrifugation, or filtration. Various possibilities exist here for reactors containing immobilized lipases, but most situations fall within one of the following cases: 1) a lipase in solid form precipitated within an organic liquid phase; 2) a lipase in soluble form in an aqueous phase and confined by a solid ultrafiltration membrane; 3) a lipase contained in an aqueous phase and confined by a surfactant liquid membrane within an organic liquid phase; 4) a lipase entrapped within a threedimensional polymeric matrix dispersed within an organic liquid phase, or dispersed within an aqueous phase; and 5) a lipase attached to a solid support and dispersed within an organic liquid phase, or dispersed within an aqueous phase. All these cases of technological feasibility and practical interest may be represented in the set of cartesian axes depicted in Figure 2 in the portion of space corresponding to the triangular pyramid outlined in bold.

There are several reactor configurations described in the literature which have been used in studies of immobilized lipases, as are depicted in Table 1 (where references are written in chronological order). Important characteristics as type of reaction, solvent (if any), substrate(s), reactor configuration, source of lipase, method of immobilization, immobilizing agent, and nature of carrier/barrier (if any) are also listed.

As discussed before, use of emulsifiers promotes formation of a pseudouniphase reaction system. However, emulsion systems have several drawbacks: rclatively low productivity, need of high-speed stirring to prevent clumping, requirement for powerful centrifuging or solvent extraction for separation of product from emulsifier, virtual impossibility of reutilization of the enzyme, and difficult control of the water concentration. These difficulties can be circumvented by immobilizing the lipase, and enclosing it via one of several possibilities, namely, in batch stirred-tank reactors (BSTRs), packed-bed reactors (PBRs), fluidized-bed reactors (FBRs), or membrane reactors.

BSTRs are the reactors most commonly used; this reactor configuration accounts for more than two thirds of all reported uses (see Table 1). These reactors operate batchwise and consist of a vessel in which the reactant fluid mixture is stirred by some mechanical means (e.g., magnetic bars, submerged impellers, reciprocal oscillators, or endover-end rotators) in a way that avoids the existence of temperature and concentration gradients. The immobilized enzyme is separated from the reaction medium at the end of the reaction by filtration or centrifugation. These reactors are easy to operate (e.g., heat, cool, clean, and maintain) and normally require a very limited set of auxiliary equipment; however, the upper average overall volumetric throughput 


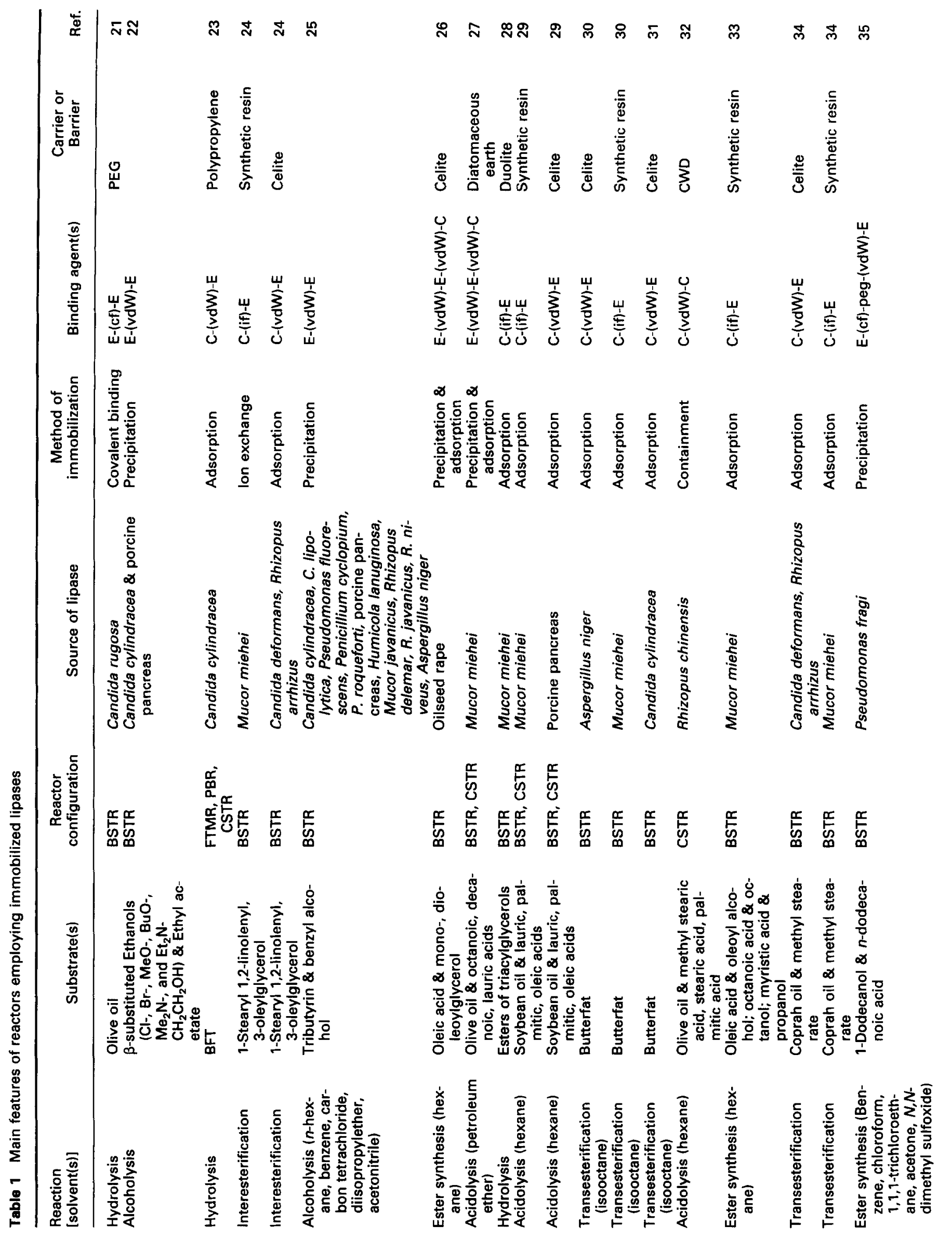




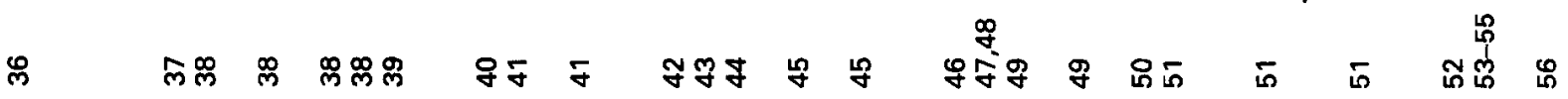

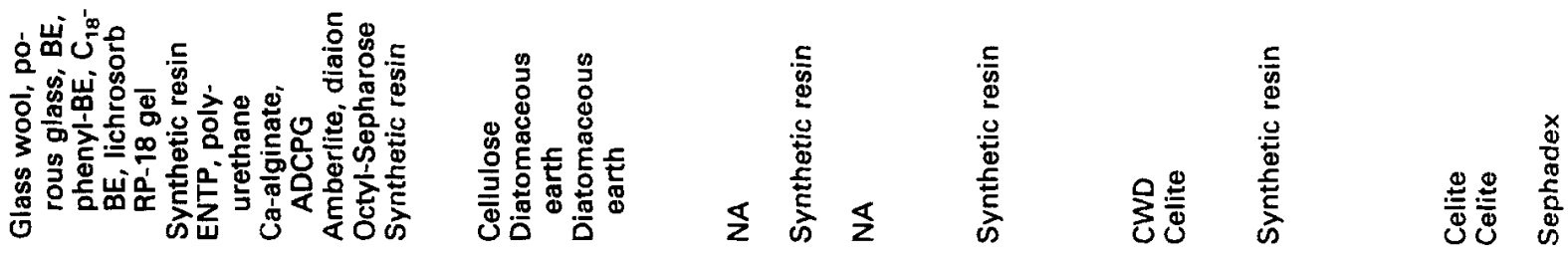

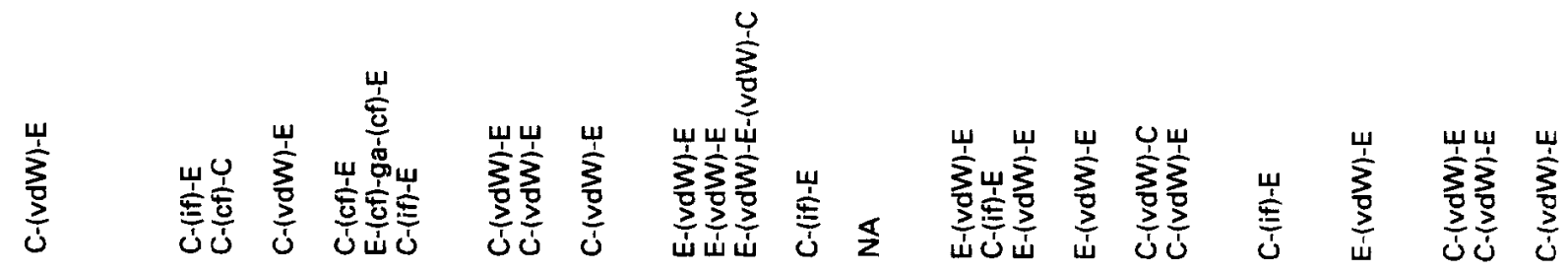

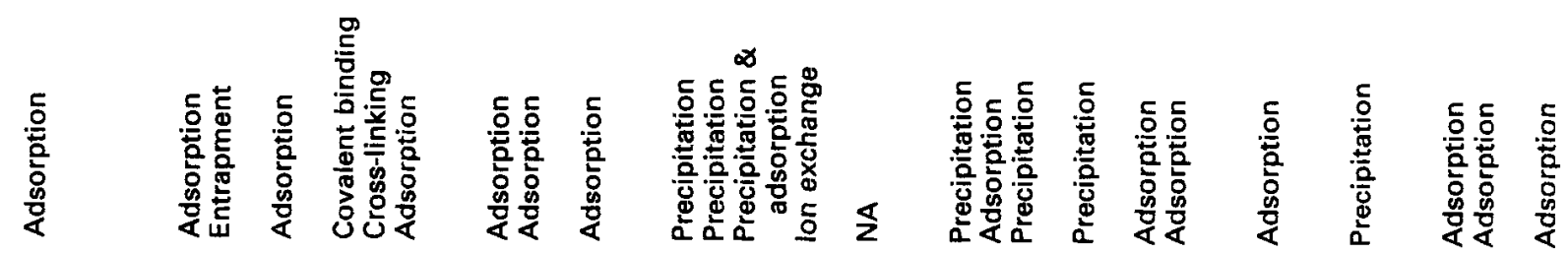

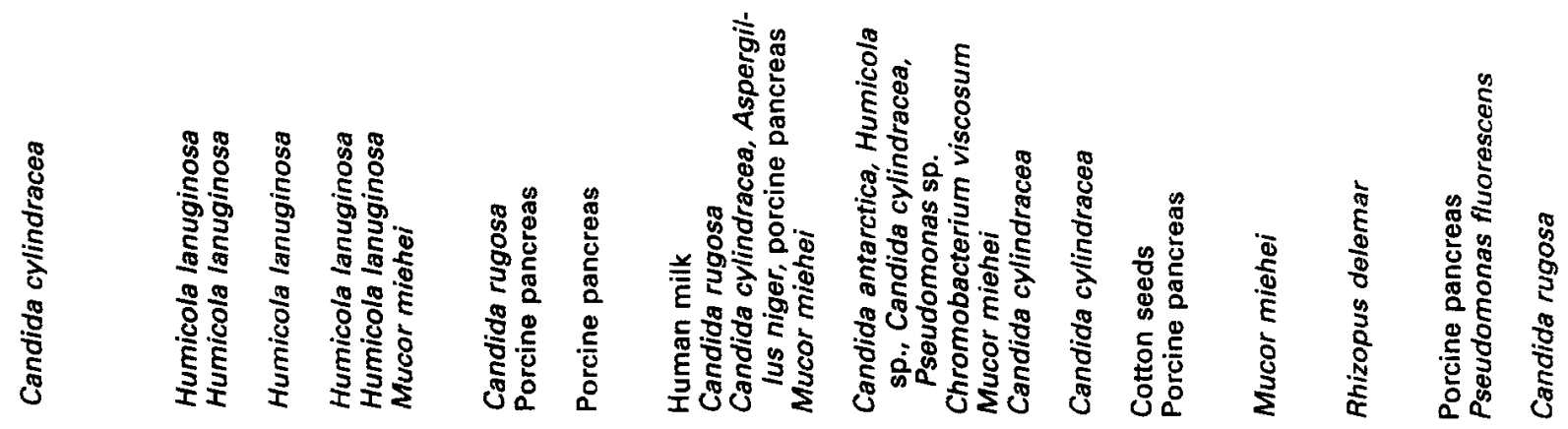

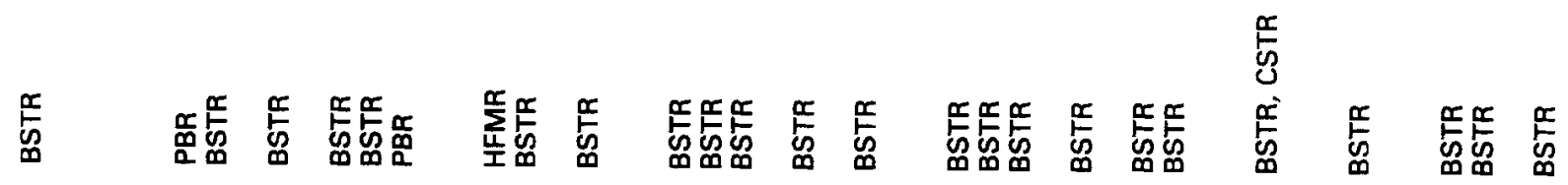

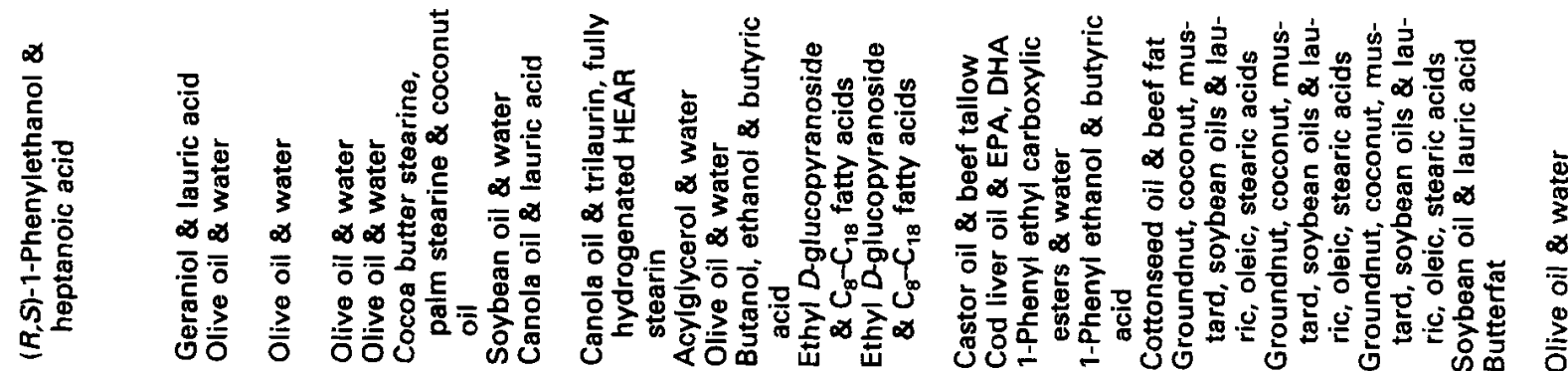

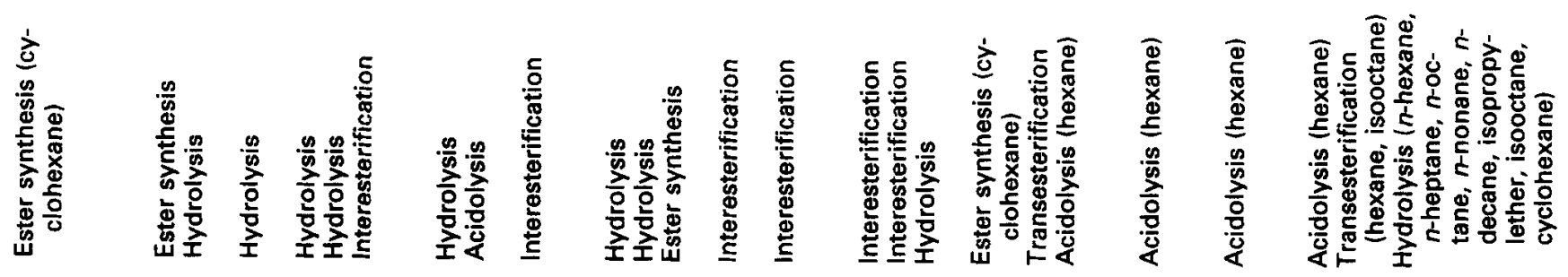




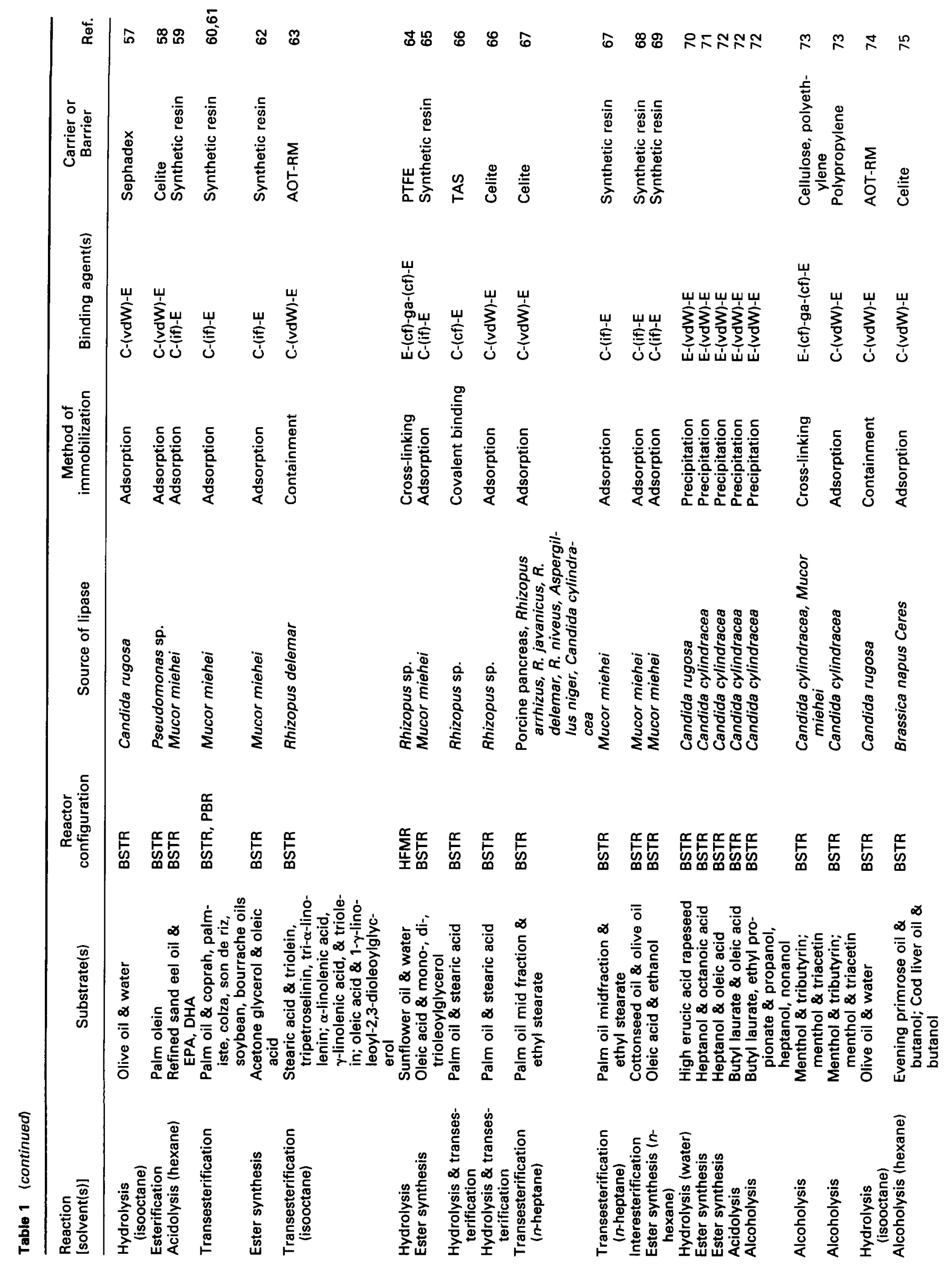




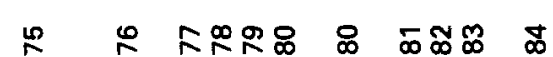

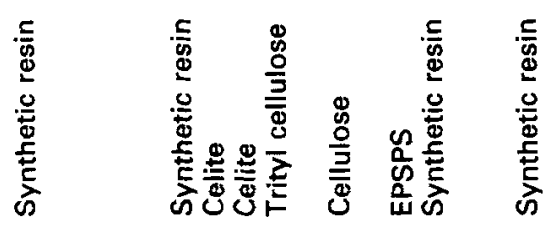

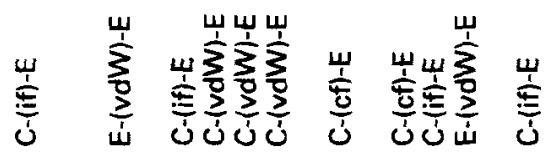

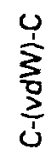

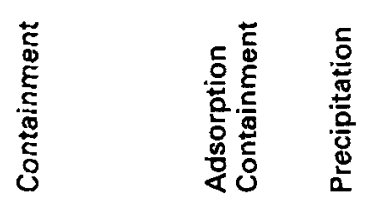

离
岁紊紊

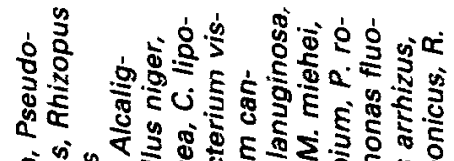

足思 命

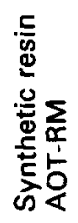

के के

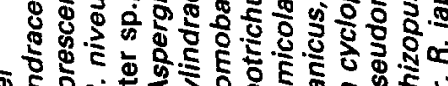
ब.

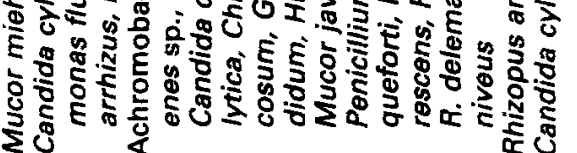

œ

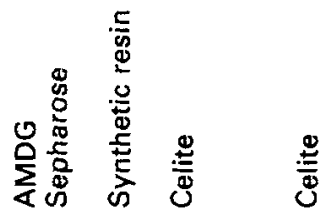

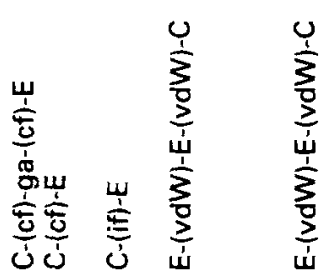
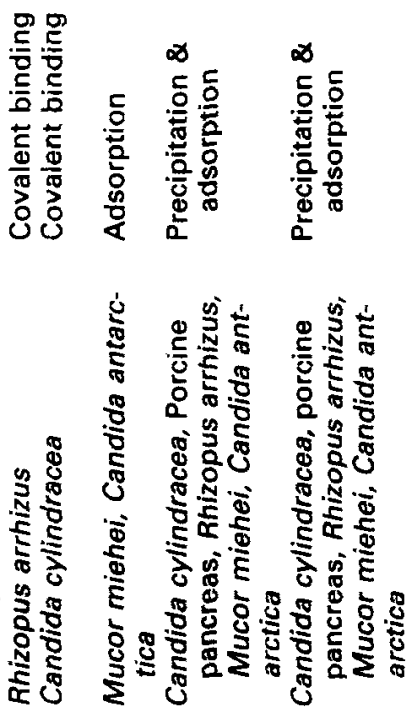

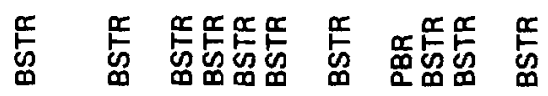

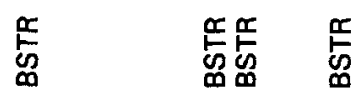

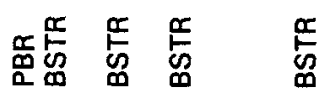

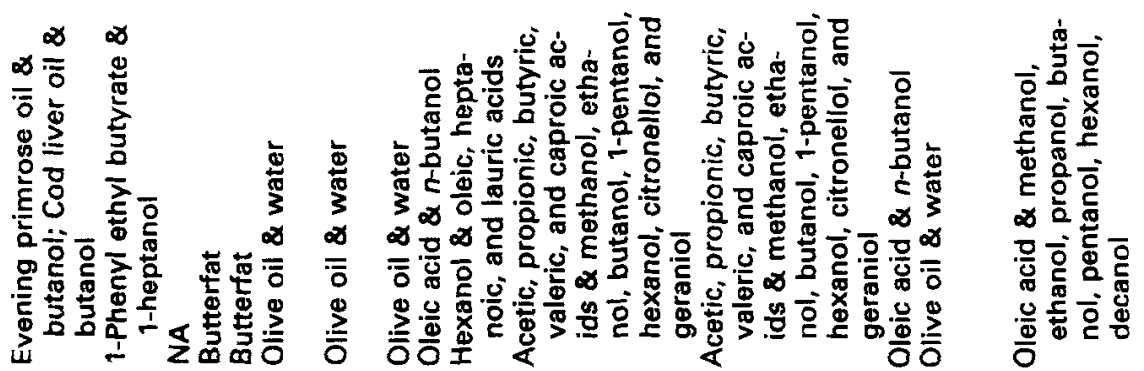

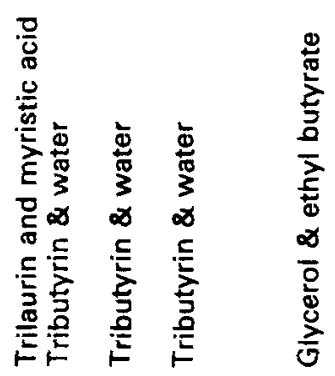
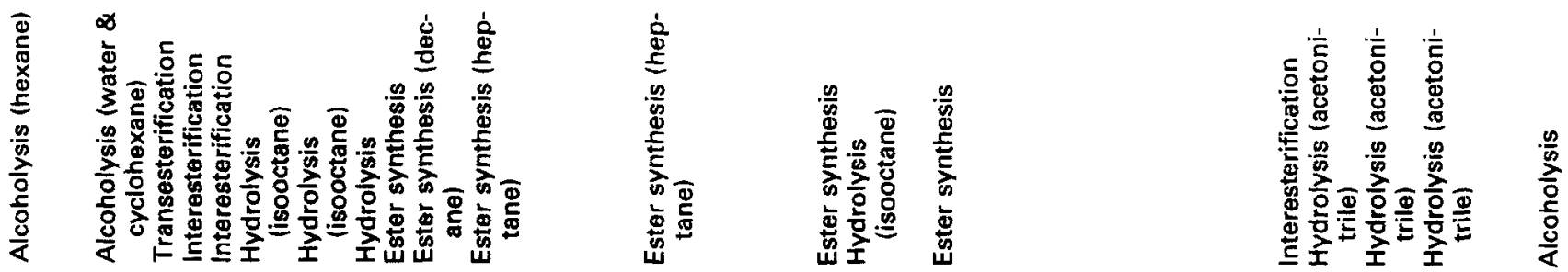


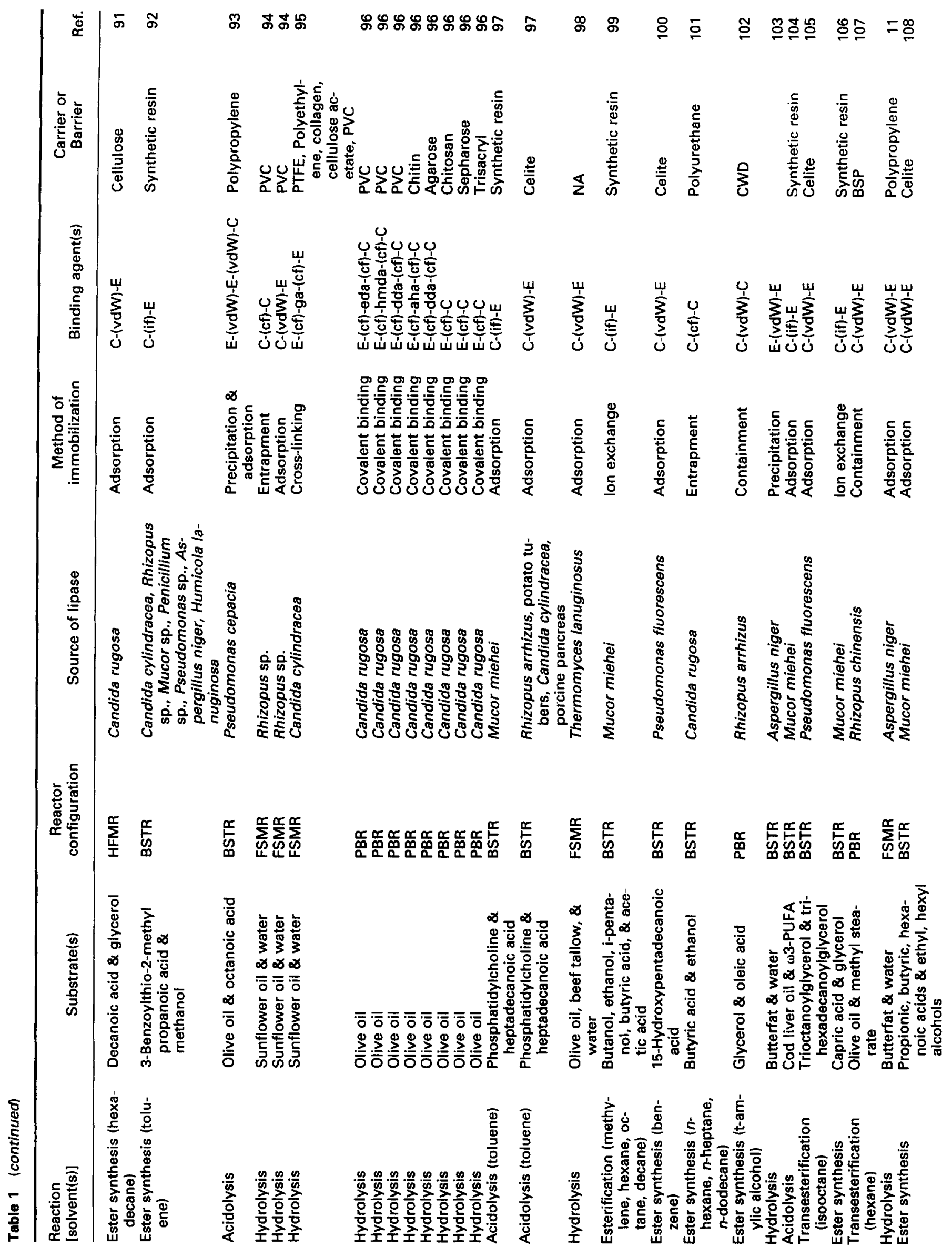




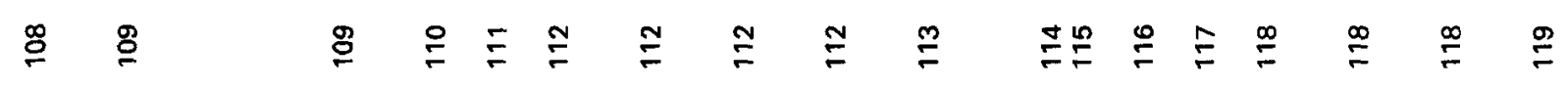
$\frac{5}{\frac{5}{2}}$

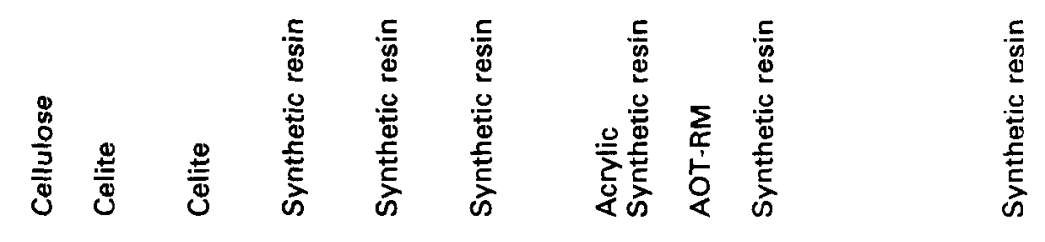

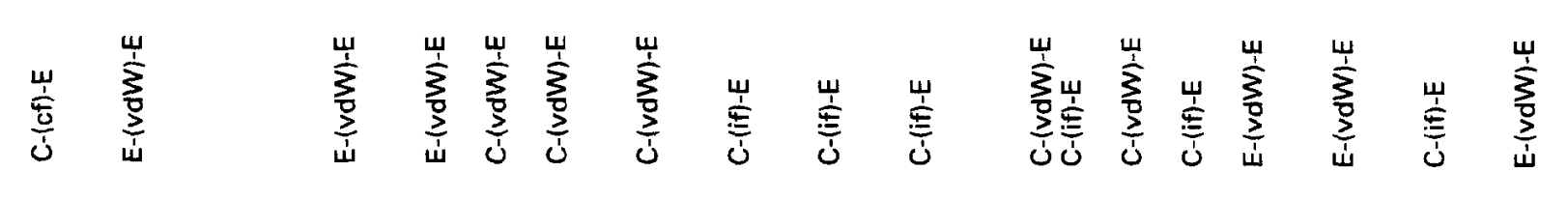

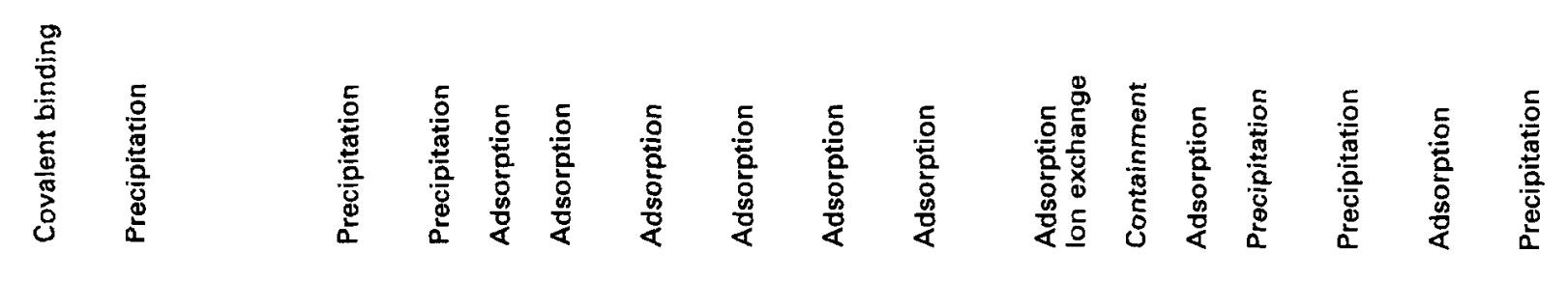

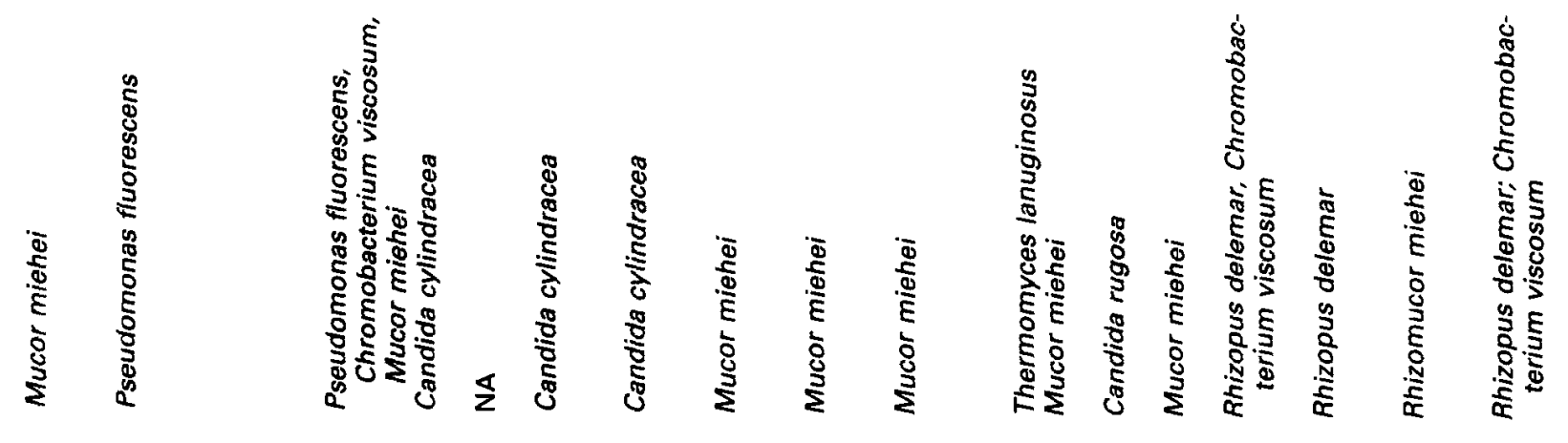

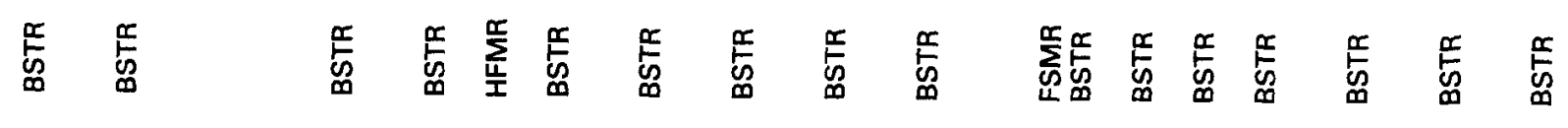

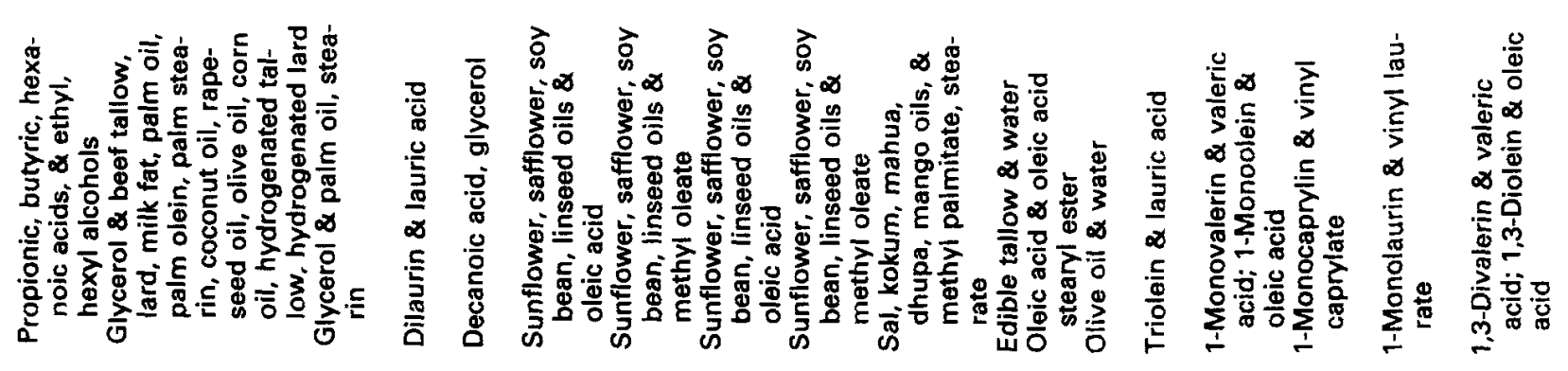

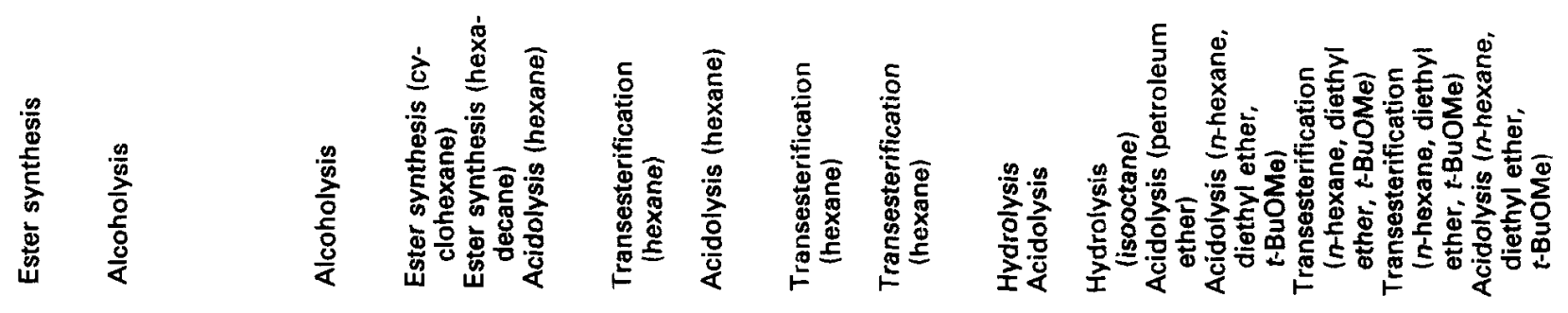




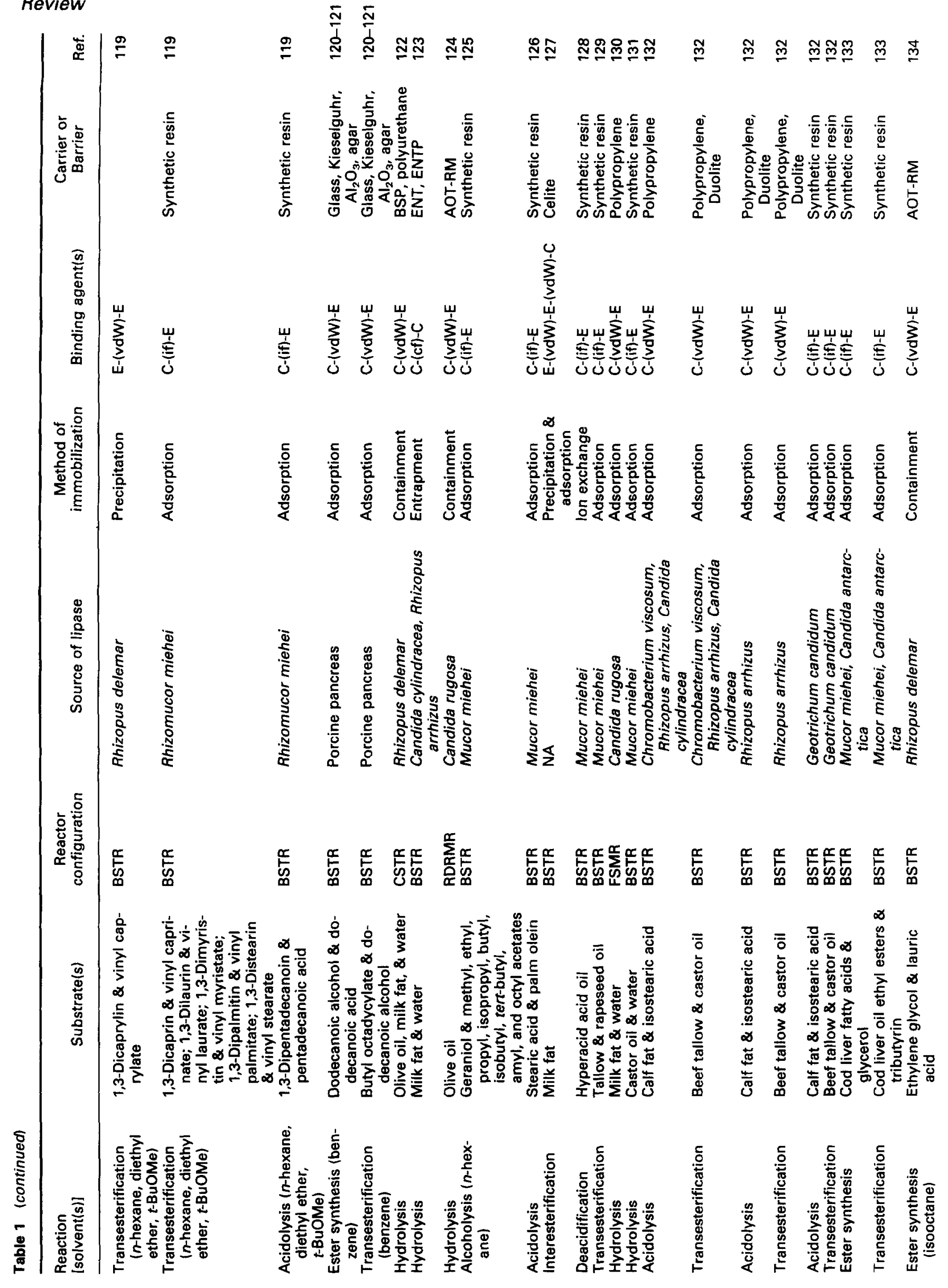




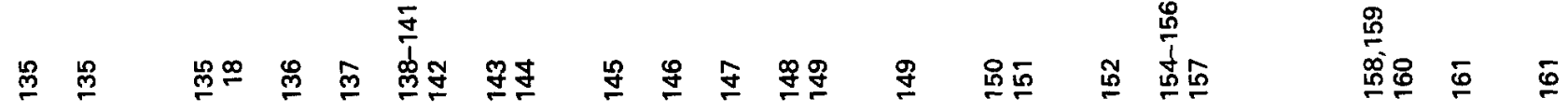

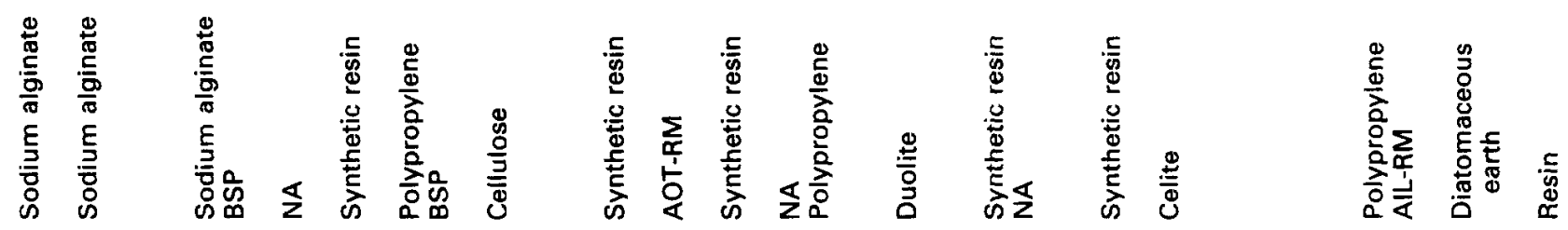

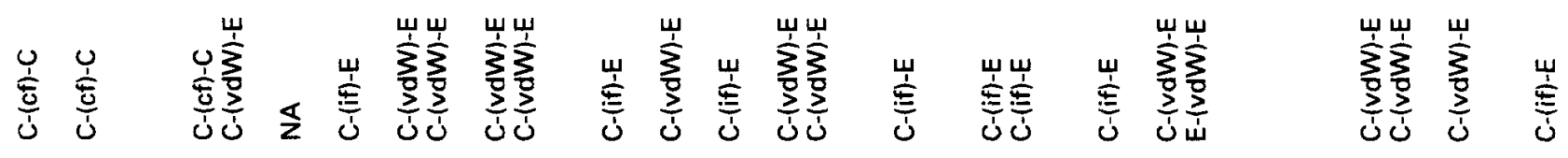
III

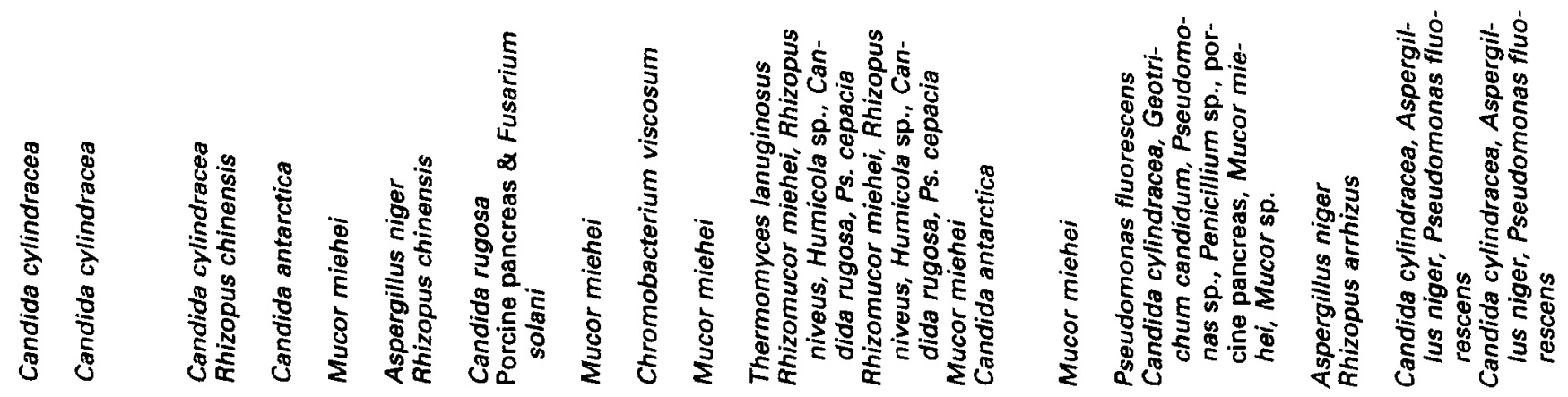

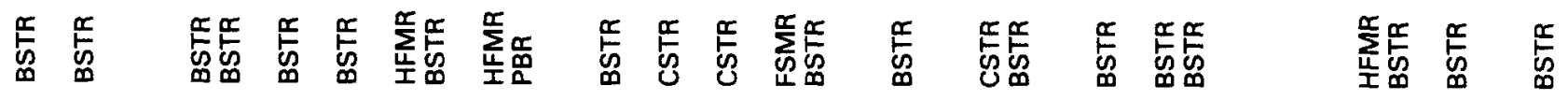

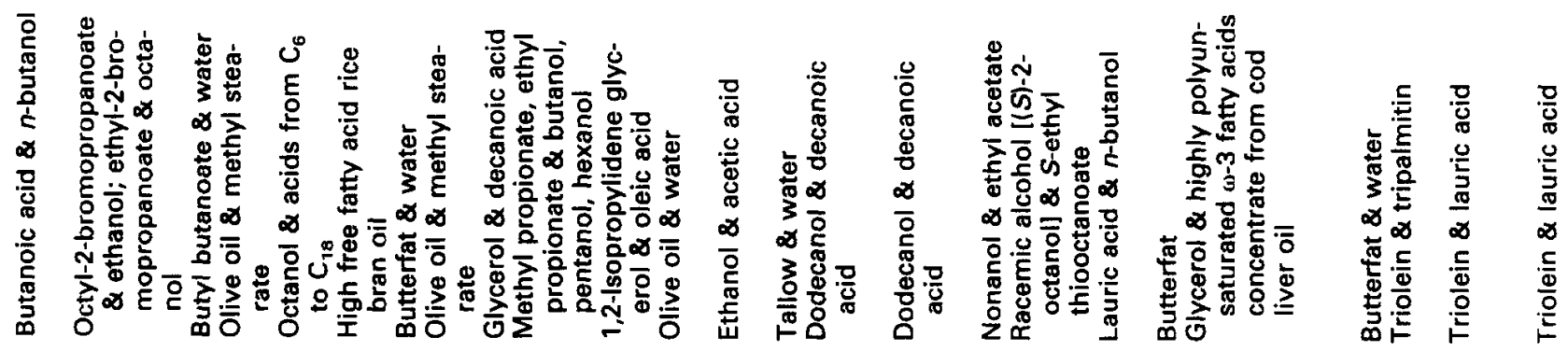

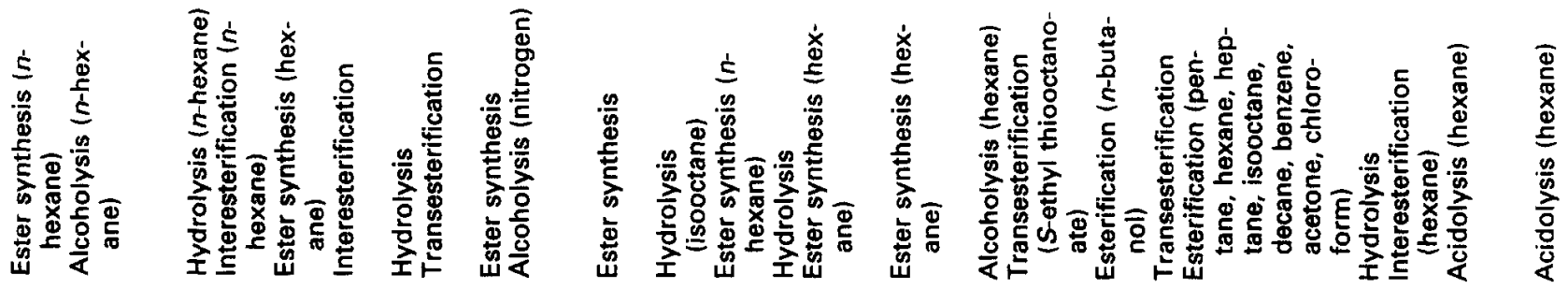




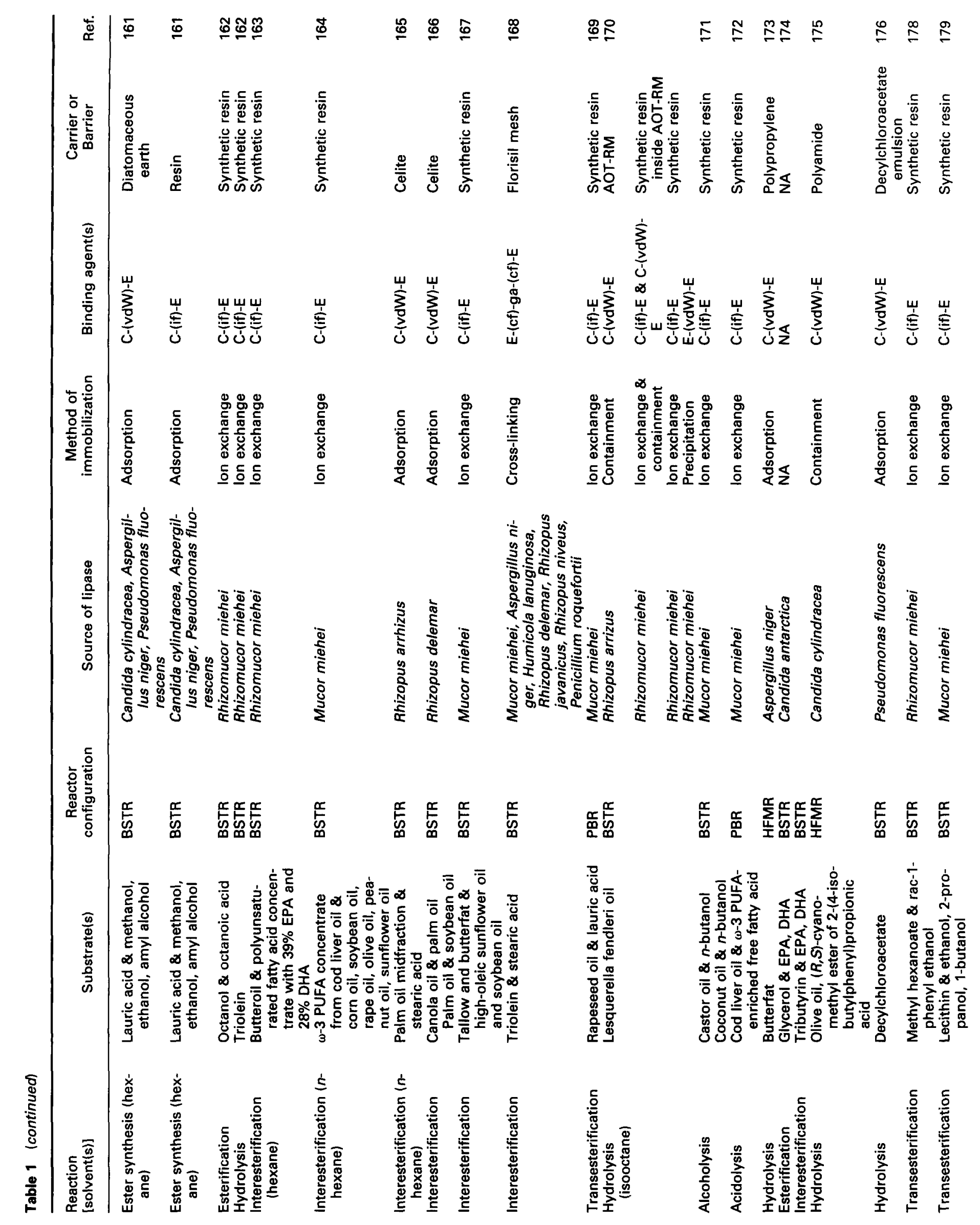




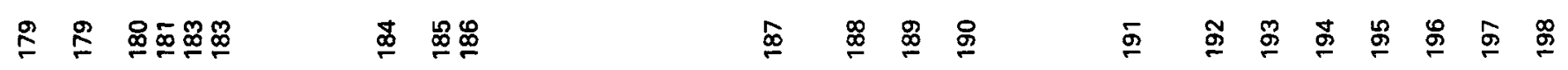

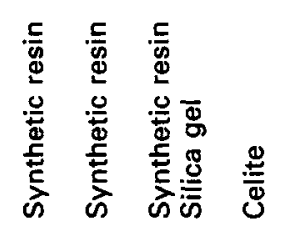

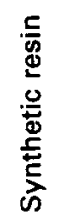

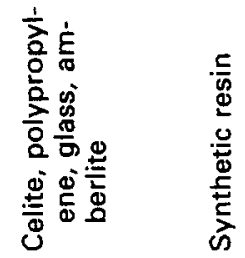

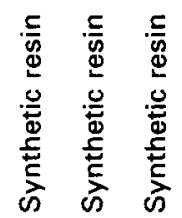

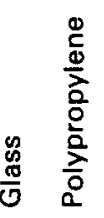

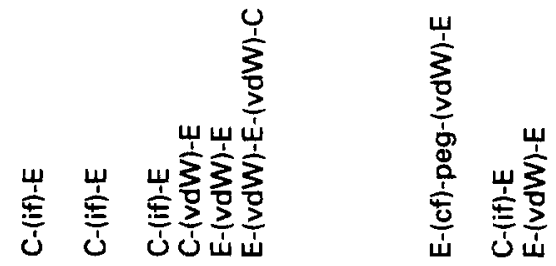

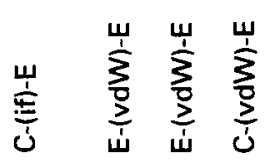

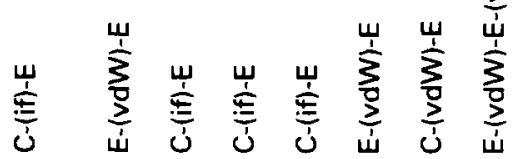

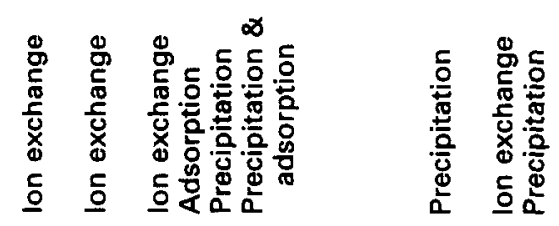

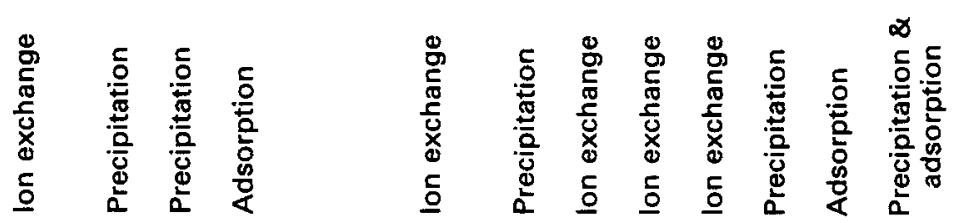

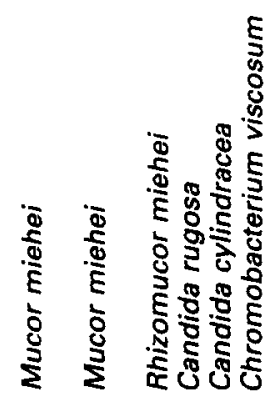

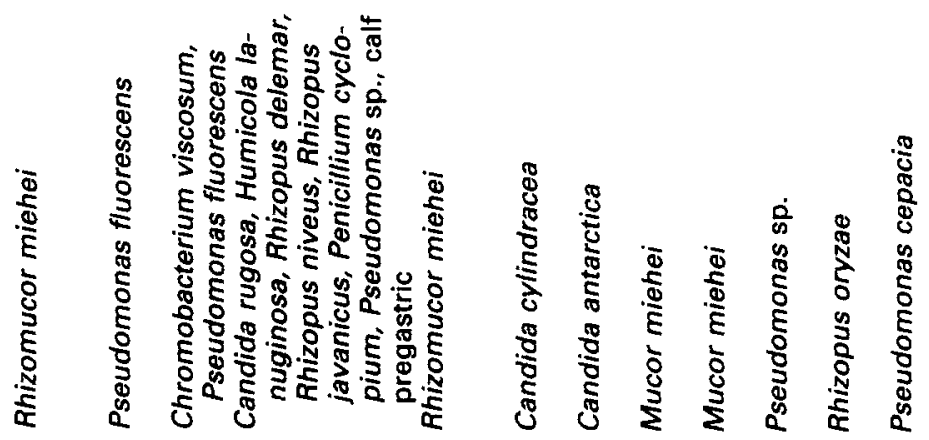

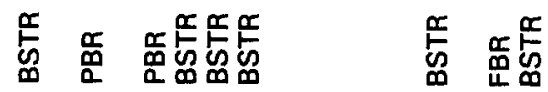

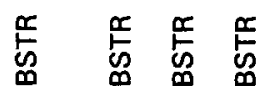

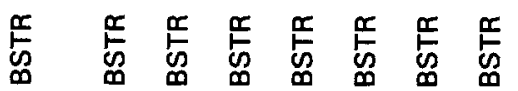

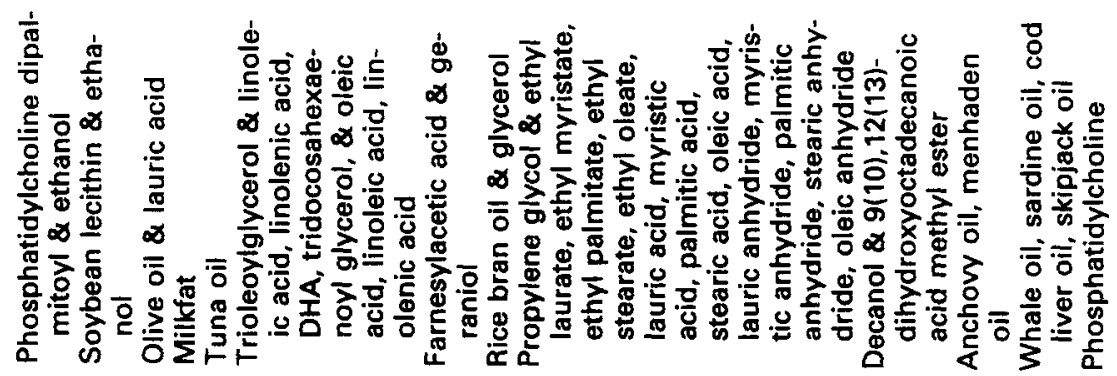

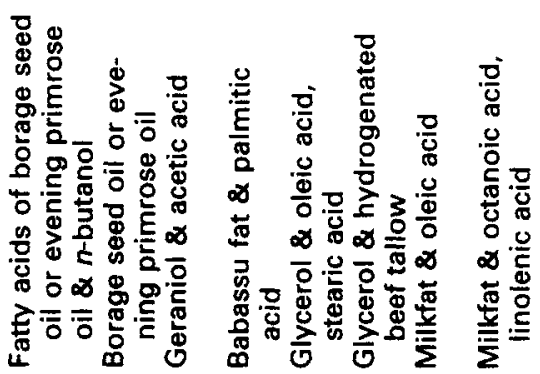

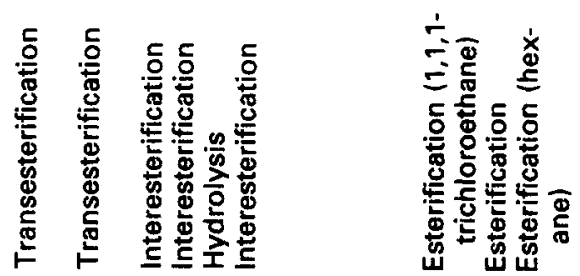

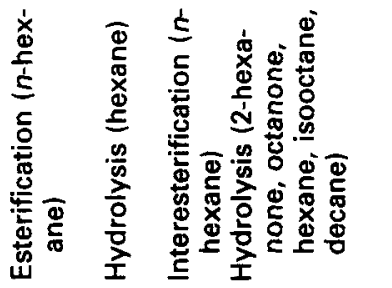

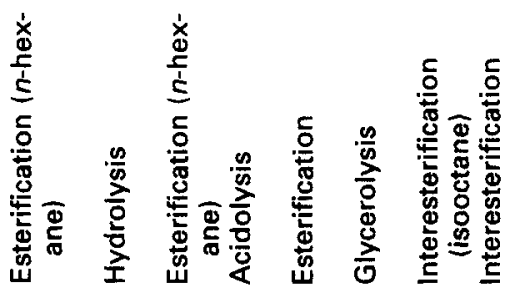




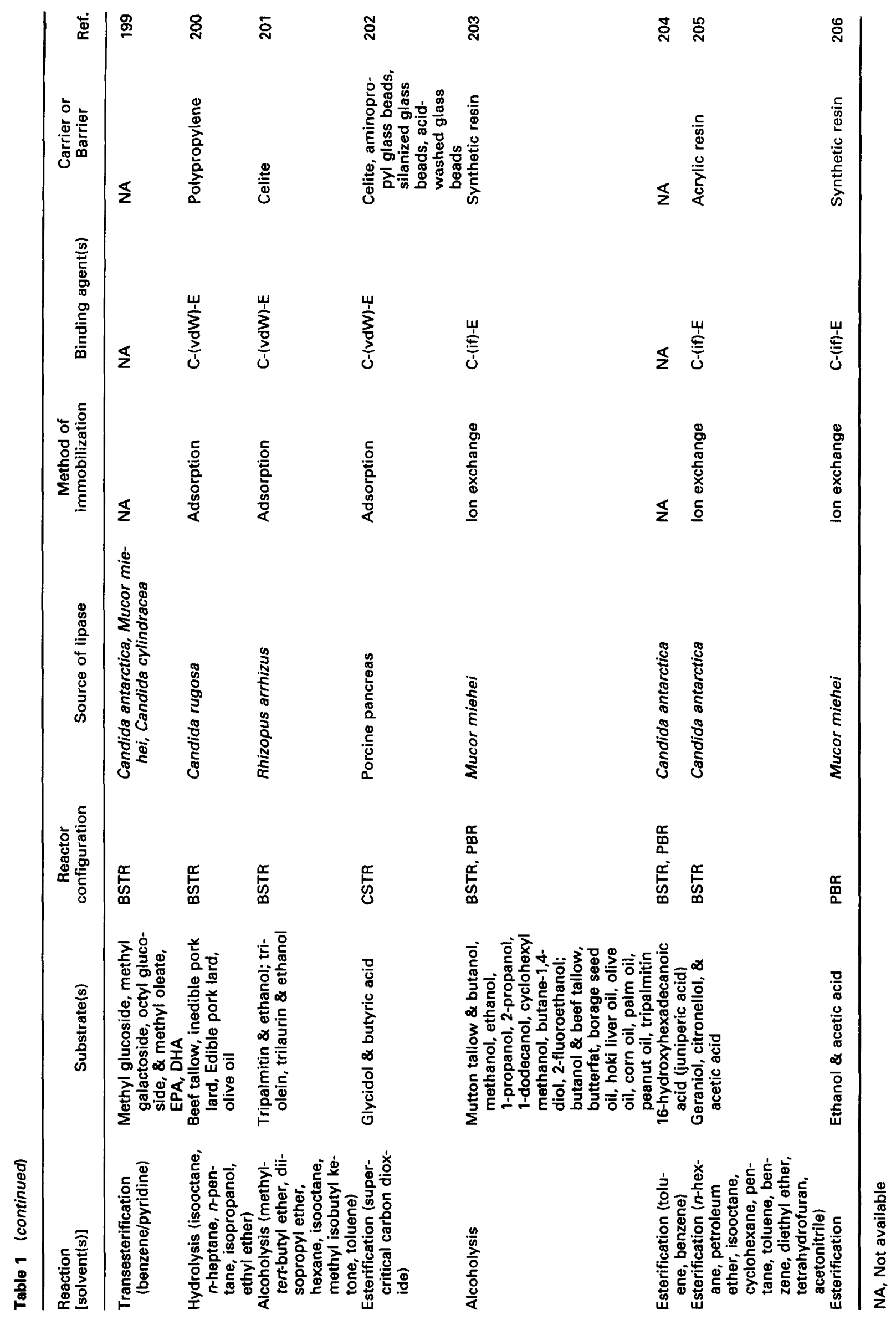


is relatively low because of dead times taken up by the operations of emptying, cleaning, and filling, and so economic considerations constrain their large scale use.

Because of their high efficiency, low cost and ease of construction, operation and maintenance, PBRs, also known as fixed-bed reactors, have traditionally been used for most large-scale catalytic reactions. In these reactors, the granules of immobilized enzyme are usually packed within a jacketed thermostatted pipe or column, thus providing a large surface area per unit volume of reaction. In the presence of a single phase, pumping may be made upward (to avoid extensive bypassing) or downward (to take advantage of gravitational forces), whereas in a biphase situation the two phases may be pumped in opposite directions (countercurrent flows) with the most dense flowing downward, or in the same direction (cocurrent flows). Great pressure drops are normally associated with this kind of reactor, especially if diffusional limitations are to be alleviated by decreasing the mesh size of the bed granules.

In CSTRs, no gradients of temperature or concentration exist, because of the efficient stirring which promotes intimate contact of the enzyme with the reaction mixture. The immobilized enzyme is retained within the reactor by means of a filter at the outlet. Low costs of construction are normally associated with these reactors, but to achieve similar degrees of conversion, a CSTR must be larger than a PBR, or a cascade should be used instead of a single unit (with concomitant problems of layout space requirements).

An FBR is, in a sense, a hybrid of a CSTR and a PBR, for which the upward linear velocity of reacting fluid is above the terminal velocity of the bed of enzyme. The usually high pump size and power requirement nevertheless prevent extensive use of this type of reactor.

Membrane or diaphragm reactors (which are in essence the linear counterpart of a PBR) may be operated with one or two liquid phases. In these reactors, the enzyme is immobilized onto the membrane, which may take either a flat sheet (FSMR) or hollow fiber (HFMR) form. Because of the role of the membrane in the segregation of two immiscible fluids, membrane reactors are commonly employed for biphasic liquid systems. Prevention and elimination of membrane pore plugging is considerably more difficult than packed-bed plugging in a PBR, but the lower pressure drops for a given specific area of reaction usually compensate for such drawback.

In what concerns the flow of the reacting fluid from the point of view of the solid carrier or barrier, a combination of two or more of the following four extreme situations arises: 1) tangential flow or 2) normal flow (which occur usually with membranes in either FSMRs or HFMRs), and 3) contour flow and 4) random flow (which are typical of particulate solids as in PBRs). If two liquid phases are flown tangentially, their relative direction of motion may also be classified as cocurrent or countercurrent. The tangential flow occurs in membrane reactors operated continuously, or operated batchwise under total recycle conditions; the normal flow corresponds to bulk flow of the reaction system through the carrier or the barrier, and again is typical of membrane reactors; the random flow encompasses BSTRs and CSTRs, as well as FBRs; and the contour flow is found in PBRs with or without recycle. The pumping requirements increase usually in the order of: tangential flow, normal flow, contour flow, and random flow; preselection of one of these types of flow usually results from a compromise between the high activity of immobilized enzyme (available surface area for immobilization is considerably different for the various types of flows described) and low pressure drops.

An inspection of Table 1 indicates that among all immobilization protocols, adsorption has been clearly elected by most researchers. The ease of immobilization, absence of expensive and toxic chemicals, ability to retain the specific activity and selectivity of the lipase virtually unchanged with respect to its soluble form, and feasibility of regeneration (based on the partial reversibility of the immobilization technique) may partially account for this realization. Examples of physicochemical parameters able to describe adsorbed lipases are given in Tables 2 and 3. The model entertained there is the classical Langmuir adsorption isotherm, $C_{l i p, a d s}=C_{l i p, a d s, \max } K_{l i p} C_{l i p, f r e e} /\left(1+K_{l i p} C_{l i p, f r e e}\right)$, where $C_{\text {lip.ads }}$ is the concentration of lipase adsorbed, $C_{\text {lip.free }}$ is the concentration of lipase in the bulk of the supernatant solution, $K_{l i p}$ is an adsorption equilibrium constant, and $C_{l i p, a d s, \max }$ is the maximum concentration of lipase that can ever be adsorbed. It has been shown ${ }^{7}$ that this model provides accurate (empiric) fittings to adsorption data of several enzymes even though the theoretical assumptions underlying it are not at all met by proteins. The temperature dependence of $K_{l i p}$ can be expressed via van't Hoff's relationship in view of its (tentative) nature of an equilibrium constant, viz. $K_{\text {lip }}=\beta \exp \left\{-\Delta h_{\text {lip,ads }} / R T\right\}$, where $\beta$ is a preexponential constant, $R$ is the ideal gas constant, $T$ denotes the absolute temperature, and $\Delta h_{\text {lip,ads }}$ represents the standard enthalpy change accompanying the adsorption of lipase onto the membrane surface. The values suggested for $\Delta h_{\text {lip,ads }}{ }^{7}$ were $5.3 \mathrm{~kJ} \mathrm{~mol}^{-1}$ (for the overall protein) and $20.5 \mathrm{~kJ} \mathrm{~mol}^{-1}$ (for the lipase), both of which

Table 2 Maximum coverage for adsorption of lipase

\begin{tabular}{|c|c|c|c|c|}
\hline \multicolumn{5}{|c|}{ Saturation coverage } \\
\hline Values & Units & $\begin{array}{c}\text { Temp. } \\
\left({ }^{\circ} \mathrm{C}\right)\end{array}$ & $\mathrm{pH}$ & Ref. \\
\hline 38,000 & $A^{2}$ molecule $^{-1}$ & 35 & 7.0 & 11 \\
\hline 50 & $g_{\text {support }} g_{\text {protein }}-1$ & -20 & NA & 26 \\
\hline 4.643 & $\mathrm{~m}^{2}$ support $\mathrm{g}_{\text {protein }}{ }^{-1}$ & 30 & NA & 40 \\
\hline 111 & $m^{2}$ support $9_{\text {protein }}{ }^{-1}$ & 30 & 7.0 & 57 \\
\hline $82-103$ & $\mathrm{~m}^{2}$ support $\mathrm{g}_{\text {protain }}{ }^{-1}$ & 37 & 8.0 & 64 \\
\hline 2.5 & $\mathrm{~g}_{\text {support }} \mathrm{g}_{\text {protein }}{ }^{-1}$ & NA & NA & 79 \\
\hline 50 & $\mathrm{~g}_{\text {support }} \mathrm{g}_{\text {protein }}{ }^{-1}$ & 25 & 9.0 & 80 \\
\hline 5 & $\mathrm{~g}_{\text {support }} \mathrm{g}_{\text {protain }}{ }^{-1}$ & -15 & 7.2 & 89 \\
\hline $294.1-357.1$ & $\mathrm{~g}_{\text {support }} \mathrm{g}_{\text {protain }}-1$ & NA & 8.0 & 94 \\
\hline $3.95-41.7$ & $m^{2}$ support $g_{\text {protein }}{ }^{-1}$ & NA & 8.0 & 95 \\
\hline 10 & $\mathrm{~g}_{\text {support }} \mathrm{g}_{\text {protein }}{ }^{-1}$ & NA & 8.0 & 97 \\
\hline 250 & $\mathrm{~m}^{2}$ support $\mathrm{g}_{\text {protein }}{ }^{-1}$ & 25 & NA & 111 \\
\hline 20,030 & $\AA^{2}$ molecule $^{-1}$ & 45 & 7.0 & 130 \\
\hline $60,000-80,000$ & $\AA^{2}$ molecule ${ }^{-1}$ & $20-45$ & 7.0 & 139 \\
\hline $1,700-2,100$ & $\AA^{2}$ molecule $^{-1}$ & 25 & 8.0 & 176 \\
\hline
\end{tabular}

NA, Not available 
Table 3 Equilibrium constant for adsorption of lipase

\begin{tabular}{lccr}
\hline$K_{\text {eq }}(\mathrm{M})$ & $\begin{array}{c}\text { Temp. } \\
\left({ }^{\circ} \mathrm{C}\right)\end{array}$ & $\mathrm{pH}$ & Ref. \\
\hline 0.00000070 & 35 & 7.0 & 11 \\
$0.00000103-0.00000122$ & $20-45$ & 7.0 & 139 \\
& & & -
\end{tabular}

compare well with data obtained for other proteins, ${ }^{8}$ whereas the values found for $\beta$ were $8.17 \cdot 10^{5}$ and $9.70 \cdot 10^{5} \mathrm{dm}^{3} \mathrm{~mol}^{-1}$, respectively, also similar to the values found for hog pancreas lipase immobilized on Sepharose ${ }^{9}$ and on siliconized glass. ${ }^{10}$ Although there is no special prerequisite for selecting a particular functional form to describe the variation of the saturation coverage parameter $\left(C_{l i p, a d s, \max }\right)$ with temperature, Malcata et al. ${ }^{7}$ tested three alternative empirical approaches for correlating this parameter and concluded that $C_{l i p, a d s, \text { max }}=\alpha \exp \left\{-\Delta h_{\text {lip,sir }} / R T\right\}$, where $\alpha$ and $\Delta h_{\text {lip,sit }}$ are constants, provided the best fit. The results in Tables 2 and 3 are useful for the prediction of the amount of lipase that can be adsorbed onto a given support, which in principle correlates with the lipolytic activity that will be available.

The principle of reversibility in adsorption of lipase has been questioned based on the observation that desorption of the lipase into plain aqueous buffer does not occur significantly. It has been claimed ${ }^{11}$ that during the adsorption process, the protein molecules which are essentially folded in the beginning and thus able to contact the surface at only one site (or, at most, at a very limited number of sites) begin slowly to unfold upon contact, thus allowing more of their surface to come into contact with the support and consequently creating a multiplicity of binding sites; although breakage of contact at a single site is quite feasible, desorption via simultaneous detachment of the protein segments from all binding sites is an extremely improbable event. This pseudoadsorption process is assumed to basically consist of a temporary reversible alteration of the lipase conformation upon change of the nature of the microenvironment with concomitant lowering of the total Gibbs' free energy of the system (as required for a spontaneous process), which eventually becomes irreversible; the forward process (that is, adsorption) is expected to be largely favored when compared with the reverse process (that is, desorption) in the case of lipases, as these enzymes are especially hydrophobic. However, proteins may desorb rcadily upon addition of a component possessing larger free energy of adsorption (e.g., another protein), which will compete for binding sites with the already bound protein, or of a solvent possessing both hydrophilic and hydrophobic character (e.g., ethanol).

In terms of the design of immobilized lipase reactors, consideration of the time scales associated with the physicochemical processes in question should be made. Three major types of processes are to be considered: 1) transport of the reactant (product) molecules of reactants from (to) the bulk of the reaction system to (from) the vicinity of the immobilized lipase, 2) transformation of the reactant molecules by chemical reaction catalyzed by the immobilized lipase, and 3) deactivation of the immobilized lipase. The order of magnitude analyses, based on the assumptions that these processes are essentially diffusion-driven (with diffusivity $D$ and molecular path $L$ ), and described by MichaelisMenten kinetics (with maximum rate $v_{\max }$ ) and first-order decay (with rate constant $k_{d}$ ), respectively, indicate that good estimates of the time scales associated therewith are given by $L^{2} / D, C_{0} / v_{\max }$ and $1 / k_{d}$, respectively, where $C_{0}$ is the initial concentration of limiting substrate. If $L^{2} / D \ll$ $C_{0} / v_{\max } \ll 1 / k_{d}$, then the process is kinetically controlled; if $C_{0} / v_{\max } \ll L^{2} / D \ll 1 / k_{d}$, then the process is diffusion controlled; if $1 / k_{d} \ll C_{0} / v_{\max }, L^{2} / D$, then the process is deactivation controlled. Knowledge of the controlling factor al-

Table 4 Total number of independent chemical reactions naturally catalyzed by lipases (first row) and type of such reactions (second row $)^{\mathrm{a}}$

\begin{tabular}{|c|c|c|c|c|}
\hline & Glycerol & Monoglyceride & Diglyceride & Triglyceride \\
\hline Water & & $3 \mathrm{~N}$ (hydrolysis) & $6 \mathrm{~N}^{2}$ (hydrolysis) & $3 N^{3}$ (hydrolysis) \\
\hline Fatty acid & $\begin{array}{l}3 \mathrm{~N} \text { (ester } \\
\text { synthesis) }\end{array}$ & $6 \mathrm{~N}^{2}$ (acidolysis) & $3 \mathrm{~N}^{3}$ (acidolysis) & $3 N^{4}-3 N^{3}$ (acidolysis) \\
\hline Glycerol & & $6 \mathrm{~N}$ (alcoholysis) & $18 N^{2}-6 N$ (alcoholysis) & $9 \mathrm{~N}^{3}$ (alcoholysis) \\
\hline Monoglyceride & & $15 \mathrm{~N}^{2}$ (alcoholysis) & $\begin{array}{l}45 N^{3}-45 N^{2}+78 N \\
\text { (alcoholysis) }\end{array}$ & $18 N^{4}-12 N$ (alcoholysis) \\
\hline & & $\begin{array}{l}36 N^{2}-6 N \\
\quad \text { (transesterification) }\end{array}$ & $\begin{array}{l}99 N^{3}+9 N^{2}-36 N \\
\quad(\text { transesterification) }\end{array}$ & $\begin{array}{l}18 N^{4}+21 N^{3}-72 N^{2}+66 N \\
\quad \text { (transesterification) }\end{array}$ \\
\hline Diglyceride & & & $\begin{array}{l}24 N^{4}-24 N^{2}-4 N-14 \\
\text { (alcoholysis) }\end{array}$ & $\begin{array}{l}9 N^{5}-12 N \\
\quad \text { (alcoholysis) }\end{array}$ \\
\hline & & & $\begin{array}{l}72 N^{4}+44 N^{2}-236 N \\
\text { (transesterification) }\end{array}$ & $\begin{array}{l}36 N^{5}-108 N^{2} \\
\text { (transesterification) }\end{array}$ \\
\hline Triglyceride & & & & $\begin{array}{l}\left(18 N^{8}-18 N^{7}+81 N^{4}-215 N^{2}-150 N-16\right) / 4 \\
\quad(\text { transesterification) }\end{array}$ \\
\hline
\end{tabular}

\footnotetext{
a $N$ denotes the total number of different fatty acid, or acyl, moieties (either in free or bound form) in the reaction system under consideration. (An independent chemical reaction is assumed to consist on the chemical displacement of one acyl moiety or the chemical exchange of two acyl moieties; any molecular event that leads to the formation of products which are analogous to the reactants is not considered to be an independent chemical reaction.)
} 
Table 5 Half-lives for reactions catalyzed by immobilized lipases

\begin{tabular}{cccr}
\hline$t_{1 / 2}(\mathrm{~h})$ & Temp. $\left({ }^{\circ} \mathrm{C}\right)$ & $\mathrm{pH}$ & Ref. \\
\hline 477 & 35 & 7.0 & 11 \\
7.0 & 45 & NA & 21 \\
$110-5,680$ & $35-40$ & 7.0 & 23 \\
912 & NA & NA & 37 \\
552 & 60 & NA & 39 \\
1,032 & 30 & 6.0 & 40 \\
$240-480$ & 40 & NA & 62 \\
$26.4-180$ & 37 & 8.0 & 64 \\
0.12 & 50 & 9.0 & 80 \\
$33-138$ & $20-70$ & NA & 82 \\
$120-768$ & 37 & 8.0 & 94 \\
400 & 30 & 7.0 & 96 \\
1,200 & 40 & NA & 107 \\
1,200 & 40 & NA & 143 \\
480 & 40 & NA & 153 \\
& & & \\
\hline
\end{tabular}

NA, Not available

lows one to devise ways to improve the kinetic performance of the reactor in an educated fashion. Data and discussion pertaining to these parameters and to the rate expressions containing them which describe reactions catalyzed by immobilized lipases are presented in the next section.

\section{Activity, stability, optimum operating conditions, and economic assessments}

The number of reactions catalyzed by lipases increases rapidly as the number of existing fatty acid moieties increases (remember that oils and fats of natural origin are complex feedstocks with several fatty acid residues). If one considers only the reactions naturally catalyzed by lipases, i.e., the breakdown of tri-, di-, and monoglycerides by hydrolysis; the esterification of glycerol, mono-, and diglycerides with fatty acids; and the various combinations of these reactions falling under the denomination of interesterifications, and if the different fatty acid moieties susceptible to lipase catalytic action number up to $N$, then the total number of possible independent chemical reactions is shown in Table 4. Such a number is paramount for as few moieties as 10 . For this reason, most attempts to develop accurate rate expressions have been based either on experimental data encompassing virtually pure reactants coupled with (complex) rate expressions, or on lumped experimental data obtained for natural (complex) systems coupled with simplified lumped rate expressions. Detailed kinetic mechanisms and associated rate expressions depart from the scope of this communication, where only parameter estimates based on such simplifications as the assumption of first-order behavior for the lipase deactivation reactions and the assumption of Michaelis-Menten behavior for the lipase-catalyzed reactions are considered. Lists of the parameters associated with those two mechanisms for immobilized lipases are given in Tables 5 and 6.

The activation energies associated with $v_{\max }$ and $k_{d}$ are listed in Table 7 under the assumption that both parameters follow the (empirical) Arrhenius law; as expected, the activation energies for the deactivation of lipases are in general considerably higher than those for lipase-catalyzed reactions, but within the usual range for hydrolases (from 65.7 to $615.0 \mathrm{~kJ} \cdot \mathrm{mol}^{-112,13}$ ). When one compares the values of

Table 6 (Apparent) values for $v_{\max }$ and $K_{m}$ for reactions catalyzed by immobilized lipases

\begin{tabular}{|c|c|c|c|c|c|}
\hline \multicolumn{6}{|l|}{$v_{\max }$} \\
\hline Values & Units & $K_{m}(\mathrm{M})$ & Temp. $\left({ }^{\circ} \mathrm{C}\right)$ & $\mathrm{pH}$ & Ref. \\
\hline 0.06476 & $\mu \mathrm{mol}_{\text {product }}\left(\mathrm{min} \cdot \mathrm{cm}^{2} \text { support }\right)^{-1}$ & 0.141 & 35 & 7.0 & 11 \\
\hline $2.0-25.0$ & $\mu \mathrm{mol}_{\text {product }}\left(\mathrm{min} \cdot \mathrm{mg}_{\text {protein }}\right)^{-1}$ & $0.05-0.033$ & 25 & NA & 35 \\
\hline $0.005-2.29$ & $\mathbf{g}_{\text {product }}(I \cdot h)^{-1}$ & NA & 30 & 8.0 & 44 \\
\hline 0.04 & $\mathbf{g}_{\text {product }}(1 \cdot h)^{-1}$ & NA & 30 & 7.0 & 44 \\
\hline 0.68 & $\mathbf{g}_{\text {product }}(1 \cdot h)^{-1}$ & NA & 30 & 6.0 & 44 \\
\hline $0.001-15.2$ & $g_{\text {product }}(1 \cdot h)^{-1}$ & NA & 50 & 8.0 & 44 \\
\hline 0.003 & $\mathbf{g}_{\text {product }}(1 \cdot h)^{-1}$ & NA & 50 & 7.0 & 44 \\
\hline $0.006-0.034$ & $g_{\text {product }}(l \cdot h)^{-1}$ & NA & 50 & 6.0 & 44 \\
\hline $0.305-0.420$ & $\mu \mathrm{mol}_{\text {product }}\left(\mathrm{min} \cdot \mathrm{mg}_{\text {protein }}\right)^{-1}$ & $0.000032-0.00004$ & 30 & 8.0 & 52 \\
\hline $0.380-0.570$ & $\mu \mathrm{mol}_{\text {product }}\left(\mathrm{min} \cdot \mathrm{mg}_{\text {protein }}\right)^{-1}$ & $0.00004-0.000048$ & 40 & 8.0 & 52 \\
\hline 5.7 & $\mu \mathrm{mol}_{\text {product }}\left(\mathrm{min} \cdot \mathrm{mg}_{\text {protein }}\right)^{-1}$ & 0.120 & 40 & NA & 69 \\
\hline $3-182$ & $\mu \mathrm{mol}_{\text {product }}\left(\min \cdot \mathrm{g}_{\text {support }}\right)^{-1}$ & $0.092-0.420$ & 30 & NA & 99 \\
\hline $2.95-52.0$ & $\mu \mathrm{mol}_{\text {praduct }} \min ^{-1}$ & $0.000117-0.00034$ & 40 & 7.0 & 103 \\
\hline 67.1 & $\mu \mathrm{mol}_{\text {praduct }}\left(\min \cdot \mathrm{mg}_{\text {protein }}\right)^{-1}$ & 0.717 & 37 & 7.1 & 116 \\
\hline $8,000,000$ & $\mu \mathrm{mol}_{\text {product }}\left(\mathrm{min} \cdot \mathrm{mg}_{\text {protein }}\right)^{-1}$ & NA & 20 & NA & 120 \\
\hline $0.0142-0.0615$ & $\mu \mathrm{mol}_{\text {product }}\left(\mathrm{min} \cdot \mathrm{mg}_{\text {protein }}\right)^{-1}$ & NA & 40 & NA & 120 \\
\hline $0.0248-0.167$ & $\mu \mathrm{mol}_{\text {product }}\left(\min \cdot \mathrm{mg}_{\text {protein }}\right)^{-1}$ & NA & 40 & NA & 121 \\
\hline 67.1 & $\mu \mathrm{mol}_{\text {praduct }}\left(\mathrm{min} \cdot \mathrm{mg}_{\text {protein }}\right)^{-1}$ & 0.717 & 37 & 7.1 & 124 \\
\hline $5.37-7.47$ & $\mu \mathrm{mol}_{\text {product }}\left(\mathrm{min} \cdot \mathrm{g}_{\text {support }}\right)^{-1}$ & $0.058-0.128$ & 40 & NA & 125 \\
\hline $1.92-618$ & $\mu \mathrm{mol}_{\text {product }}\left(\min \cdot \mathrm{g}_{\text {suppurt }}\right)^{-1}$ & NA & NA & NA & 149 \\
\hline
\end{tabular}




\section{Review}

Table 7 Activation energies for lipase-catalyzed reactions and lipase thermal deactivation

\section{Activation energy}

(kJ $\mathrm{mol}^{-1}$ )

\begin{tabular}{lccccr}
\hline $\begin{array}{l}\text { Enzyme } \\
\text { reaction }\end{array}$ & $\begin{array}{c}\text { Enzyme } \\
\text { deactivation }\end{array}$ & $\begin{array}{c}\text { Temp. } \\
\left({ }^{\circ} \mathrm{C}\right\rangle\end{array}$ & $\mathrm{pH}$ & Ref. \\
\hline 15.9 & NA & $10-50$ & 7.0 & 57 \\
0.97 & NA & $0-130$ & NA & 82 \\
NA & $114-144$ & $40-55$ & 8.0 & 96 \\
33.5 & NA & $25-60$ & 7.0 & 122 \\
NA & 136 & $45-60$ & NA & 130 \\
34.5 & 27.2 & $40-60$ & 7.0 & 142 \\
$20.82-32.41$ & NA & $10-70$ & NA & 146 \\
8.67 & NA & $30-70$ & NA & 152 \\
24.3 & NA & $10-65$ & NA & 182 \\
\hline
\end{tabular}

NA, Not available the activation energies for lipase-catalyzed reactions with those for other immobilized hydrolases, the former seem to be somewhat lower; for lipases, activation energies range from 0.97 to $34.5 \mathrm{~kJ} \mathrm{~mol}^{-1}$, whereas for other enzymes they range from 14.33 to $49.0 \mathrm{~kJ} \mathrm{~mol}^{-1}$. $^{14.15}$ (It may be argued that the Michaelis-Menten mechanism, on the one hand, and the unimolecular deactivation mechanism, on the other, provide simplistic views of the reaction schemes in question; however, parameters $v_{\max }$ and $K_{m}$ on the one hand, and $k_{d}$ [or, equivalently, $k_{l / 2}=\ln (2) / k_{d}$ ], on the other, provide consistent frameworks for the assessment of activities and stabilities irrespective of the enzyme under consideration, and have so been used for comparative kinetic assessments since the beginning of this century.)

The effect of immobilization upon the intrinsic activity of lipases is depicted in Tables 8 and 9. Immobilization seems either to inhibit the action of lipases or dramatically

Table 8 Catalytic activity retained upon immobilization

Activity after immobilization

\begin{tabular}{|c|c|c|c|c|}
\hline Values & Units & Temp. $\left({ }^{\circ} \mathrm{C}\right)$ & $\mathrm{pH}$ & Ref. \\
\hline $\begin{array}{l}0.0723 \\
1.2-28\end{array}$ & $\begin{array}{l}\mu \mathrm{mol} \\
\text { Specific transesterification activity }\end{array}$ & $\begin{array}{l}35 \\
\text { NA }\end{array}$ & $\begin{array}{l}\text { NA } \\
\text { NA }\end{array}$ & $\begin{array}{l}11 \\
24\end{array}$ \\
\hline $10,000-10,500$ & $\mu \mathrm{mol}_{\text {product }}\left(\min \cdot \mathrm{g}_{\text {support }}\right)^{-1}$ & 40 & NA & 27 \\
\hline 34.2 & $\mu \mathrm{mol}_{\text {product }}\left(\min \cdot \mathrm{g}_{\text {support }}\right)^{-1}$ & 60 & NA & 33 \\
\hline $\begin{array}{l}0.55-3850 \\
0.19-69.8\end{array}$ & $\begin{array}{l}\mu \mathrm{mol} \\
\text { Specoduct } \\
\left.\text { Spin } \cdot \mathrm{g}_{\text {support }}\right)^{-1}\end{array}$ & $\begin{array}{l}50 \\
50\end{array}$ & $\begin{array}{l}\text { NA } \\
\text { NA }\end{array}$ & $\begin{array}{l}34 \\
34\end{array}$ \\
\hline $0.05-2.2$ & $\mu \mathrm{mol}_{\text {product }}\left(\min \cdot \mathrm{g}_{\text {enzymo }}\right)^{-1}$ & 24 & NA & 36 \\
\hline $4,800-5,000$ & $\mu \mathrm{mol}_{\text {product }}\left(\min \cdot \mathrm{g}_{\text {support }}\right)^{-1}$ & 50 & NA & 37 \\
\hline $25,000,000-181,000,000$ & $\mu \mathrm{mol}_{\text {product }}\left(\min \cdot \mathrm{g}_{\text {support }}\right)^{-1}$ & 70 & NA & 45 \\
\hline 128 & $\mu \mathrm{mol}_{\text {product }}\left(\min \cdot \mathrm{g}_{\text {support }}\right)^{-1}$ & 30 & NA & 57 \\
\hline 2,950 & $\mu \mathrm{mol}_{\text {product }}\left(\min \cdot \mathrm{g}_{\text {support }}\right)^{-1}$ & 40 & NA & 62 \\
\hline 0.1472 & $\mu \mathrm{mol}_{\text {product }}\left(\mathrm{min} \cdot \mathrm{cm}^{2} \text { support }\right)^{-1}$ & 25 & 8 & 64 \\
\hline 0.1283 & $\mu \mathrm{mol}_{\text {product }}\left(\min \cdot \mathrm{cm}^{2} \text { support }\right)^{-1}$ & 25 & 10.0 & 64 \\
\hline 0.1263 & $\mu \mathrm{mol}_{\text {product }}\left(\mathrm{min} \cdot \mathrm{cm}^{2}{ }_{\text {support }}\right)^{-1}$ & 37 & 8.0 & 64 \\
\hline 0.1253 & $\mu \mathrm{mol}_{\text {product }}\left(\mathrm{min} \cdot \mathrm{cm}^{2}{ }_{\text {support }}\right)^{-1}$ & 37 & 10.0 & 64 \\
\hline 0.1390 & $\mu \mathrm{mol}_{\text {product }}\left(\min \cdot \mathrm{cm}^{2}{ }_{\text {support }}\right)^{-1}$ & 60 & 8.0 & 64 \\
\hline 0.1716 & $\mu \mathrm{mol}_{\text {product }}\left(\mathrm{min} \cdot \mathrm{cm}^{2}{ }_{\text {support }}\right)^{-1}$ & 60 & 10.0 & 64 \\
\hline 200 & $\mu \mathrm{mol}_{\text {product }}\left(\min \cdot \mathrm{g}_{\text {support }}\right)^{-1}$ & 40 & NA & 69 \\
\hline 8,000 & $\mu \mathrm{mol}_{\text {product }}\left(\min \cdot \mathrm{g}_{\text {support }}\right)^{-1}$ & 40 & NA & 81 \\
\hline 23 & $\left.\mu \mathrm{mol}\right|_{\text {product }}\left(\min \cdot \mathrm{g}_{\text {support }}\right)^{-1}$ & $20-70$ & NA & 82 \\
\hline 23 & $\mu \mathrm{mol}_{\text {product }}\left(\mathrm{min} \cdot \mathrm{g}_{\text {support }}\right)^{-1}$ & $20-70$ & NA & 85 \\
\hline 0.021 & $\mu \mathrm{mol}_{\text {product }}\left(\mathrm{min} \cdot \mathrm{cm}^{2}{ }_{\text {support }}\right)^{-1}$ & 25 & NA & 91 \\
\hline $1,000-1,700$ & $\mu \mathrm{mol}_{\text {product }}\left(\min \cdot \mathrm{g}_{\text {support }}\right)^{-1}$ & 37 & 8.0 & 95 \\
\hline $2.29-21.79$ & $\mu \mathrm{mol}_{\text {product }}\left(\mathrm{min} \cdot \mathrm{mI}_{\mathrm{gel}}\right)^{-1}$ & NA & 7.0 & 96 \\
\hline $0.00000389-0.0000705$ & $\mu \mathrm{mol}_{\text {product }}\left(\min \cdot \mathrm{g}_{\text {support }}\right)^{-1}$ & 40 & NA & 97 \\
\hline $75-200$ & $\mu \mathrm{mol}_{\text {product }}\left(\min \cdot \mathrm{g}_{\text {support }}\right)^{-1}$ & 30 & NA & 102 \\
\hline $31-400$ & $\mu \mathrm{mol}_{\text {product }}\left(\min \cdot \mathrm{g}_{\text {support }}\right)^{-1}$ & 40 & NA & 106 \\
\hline $78-2,100$ & $\mu \mathrm{mol}$ product $\left(\mathrm{min} \cdot \mathrm{g}_{\text {support }}\right)^{-1}$ & 40 & NA & 108 \\
\hline $0-24.8$ & $\mu \mathrm{mol}_{\text {product }}\left(\min \cdot \mathrm{g}_{\text {support }}\right)^{-1}$ & 40 & NA & 121 \\
\hline $10-2,200$ & $\mu \mathrm{mol}_{\text {product }}\left(\min \cdot \mathrm{g}_{\text {support }}\right)^{-1}$ & 60 & NA & 132 \\
\hline 27,300 & $\mu \mathrm{mol}_{\text {product }}\left(\mathrm{min} \cdot \mathrm{g}_{\text {support }}\right)^{-1}$ & 80 & NA & 136 \\
\hline 30 & $\mu \mathrm{mol}_{\text {product }}\left(\mathrm{min} \cdot \mathrm{g}_{\text {support }}\right)^{-1}$ & NA & NA & 137 \\
\hline 23 & $\mu \mathrm{mol}_{\text {product }}\left(\mathrm{min} \cdot \mathrm{g}_{\text {support }}\right)^{-1}$ & $10-70$ & NA & 146 \\
\hline 25 & BIU g $\mathrm{g}^{-1}$ & 30 & NA & 152 \\
\hline $1,150-4,500$ & BIU $g^{-1}$ & 40 & NA & 153 \\
\hline $500-650$ & $\left.\mu m o\right|_{\text {product }}\left(\min \cdot \mathrm{g}_{\text {enzyme }}\right)^{-1}$ & 20 & NA & 162 \\
\hline 4,530 & BIU $g^{-1}$ & 40 & NA & 172 \\
\hline
\end{tabular}

NA, Not available 
Table 9 Fractional activity retained by lipases upon immobilization

\begin{tabular}{lccc}
\hline $\begin{array}{l}\text { Fractional activity } \\
\text { retained }(\%)\end{array}$ & $\begin{array}{c}\text { Temp. } \\
\left({ }^{\circ} \mathrm{C}\right)\end{array}$ & $\mathrm{pH}$ & Ref. \\
\hline 14.5 & 35 & NA & 11 \\
$9-107$ & 42 & NA & 23 \\
$92.3-560$ & NA & NA & 24 \\
$280-3,489,900$ & 50 & NA & 34 \\
$0.9-90.7$ & 45 & 7.0 & 38 \\
14 & 30 & 6.0 & 40 \\
132 & 40 & NA & 108 \\
$3-226$ & 42 & NA & 190 \\
\hline
\end{tabular}

NA, Not available

enhance it. However, care should be exercised to use the same basis for the reference of activity; if amount of protein is used as a basis, the selectivity of the immobilization process toward lipase when compared with other proteins in crude lipase preparations may partially account for some of the enhancement factors reported. ${ }^{7}$

Because lipases are proteins, their conformation is affected by both $\mathrm{pH}$ and temperature, and so their catalytic power is expected to exhibit optima for these two operating parameters as happens with most enzymes; this assertion is apparent from an inspection of Tables 10 and 11. Upon immobilization, the optimum $\mathrm{pH}$ for reactions catalyzed by lipases is slightly shifted toward more alkaline values. In view of the established serine-based nucleophilic attack aided by a histidine residue working as a base, this observation is expected because the (at least) partial opening of the lid upon immobilization is likely to expose the His at the active site more directly to solution hydrogen ions, and so only less acidic conditions yield the unprotonated form of

Table 10 Optimum $\mathrm{pH}$ for reactions catalyzed by immobilized lipases compared with those for the corresponding free lipases

Optimum pH

\begin{tabular}{cccc}
\hline Before & After & $\begin{array}{c}\text { Temp. } \\
\left({ }^{\circ} \mathrm{C}\right)\end{array}$ & Ref. \\
\hline NA & 6.62 & 35 & 11 \\
4.0 & 5.0 & 40 & 23 \\
NA & 7.0 & NA & 28 \\
7.0 & $6.8-8.0$ & 45 & 38 \\
NA & $7.5-8.5$ & $45-60$ & 50 \\
NA & 7.0 & 30 & 56 \\
8.0 & 10.0 & $25-60$ & 64 \\
10.0 & 10.0 & 37 & 94 \\
7.5 & 8.5 & 37 & 96 \\
$5.0-7.0$ & $5.0-5.5$ & 35 & 122 \\
NA & 6.46 & 45 & 130 \\
7.0 & 7.0 & $50-60$ & 132 \\
NA & 7.0 & 40 & 158 \\
NA & 7.0 & 40 & 159 \\
NA & 7.0 & $30-50$ & 161 \\
8 & 8 & 25 & 175 \\
NA & 10 & 30 & 186
\end{tabular}

NA, Not available
Table 11 Optimum operating temperature for reactions catalyzed by immobilized lipases compared with those for the corresponding free lipases

Optimum temp. $\left({ }^{\circ} \mathrm{C}\right)$

\begin{tabular}{lccr}
\hline Before & After & $\mathrm{pH}$ & Ref. \\
\hline 51 & $51-61$ & 7.0 & 38 \\
NA & 60 & NA & 41 \\
NA & $50-55$ & $5.0-8.5$ & 50 \\
NA & $30-35$ & 7.0 & 57 \\
37 & 60 & $8.0-10.0$ & 64 \\
NA & $10-90$ & NA & 82 \\
NA & 37 & 10.0 & 94 \\
35 & $43-55$ & 8.0 & 96 \\
NA & $50-60$ & NA & 106 \\
NA & $40-50$ & NA & 108 \\
30 & 40 & NA & 122 \\
NA & 60 & NA & 128 \\
37 & 60 & NA & 132 \\
NA & 55 & NA & 145 \\
NA & $30-60$ & NA & 152 \\
NA & 40 & 7.0 & 158 \\
NA & 60 & NA & 167 \\
NA & 37 & NA & 168 \\
37.5 & 40 & 8 & 175 \\
NA & 37 & NA & 182 \\
NA & $10-50$ & NA & 186 \\
NA & $35-40$ & NA & 193 \\
NA & $48-60$ & NA & 196 \\
& & &
\end{tabular}

NA, Not available

the imidazolium ring required for a basic behavior. After immobilization one can also notice a shift toward higher optimum temperature values. Increasing temperature generally increases the rate of a lipase-catalyzed reaction per unit amount of active enzyme; however, increasing temperature also leads to a higher thermal deactivation rate of the lipase itself, thus yielding decreasing amounts of active enzyme. Because immobilization provides a more rigid external backbone for lipase molecules, the effect of higher temperatures in breaking the interactions that are responsible for the proper globular, catalytically active structure becomes less notorious, and so temperature optima are expected to increase.

The optimum water levels (Table 12) for lipasecatalyzed reactions vary from as low as $0.042(\% \mathrm{v} / \mathrm{v})$ to as high as $50(\% \mathrm{v} / \mathrm{v})$; such discrepancies are related to whether net esterification or net hydrolysis is sought, respectively. Nil values are not suitable, because stripping of catalytic water from the vicinity of the lipase would not permit enzyme action; on the other hand, water levels above stoichiometry ratios do not favor the conversion extent, and also help in increasing the deactivation rate of the lipase.

A chemical catalyst such as metallic sodium, which is used to promote acyl migration among glyceride molecules, distributes the acyl residues randomly among them. By exploiting the specificity of lipases, however, it is possible to produce more useful glyceride mixtures by selective interesterification. In view of the effect of water in determining the dominant direction of a lipase-catalyzed process, maximum productivity of triglyceride and low concentration of 
Table 12 Optimum water concentration for reactions catalyzed by immobilized lipases

Optimum water concentration

\begin{tabular}{|c|c|c|c|c|c|}
\hline Values & Units & Type of reaction & Temp. $\left({ }^{\circ} \mathrm{C}\right)$ & $\mathrm{pH}$ & Ref. \\
\hline $\begin{array}{c}7,100 \\
40-50 \\
0-1 \\
10,000 \\
12.5-23.3 \\
448 \\
0.042-0.098 \\
100 \\
\leqslant 1 \\
0-10 \\
3 \\
-100 \\
2.5 \\
0.32-0.97 \\
100,000 \\
0.25 \\
350,000-400,000 \\
0.84 \\
0.002 \\
1000 \\
0.43 \\
200,000-250,000\end{array}$ & $\begin{array}{l}\text { ppm } \\
\% v / v \\
\% v / v \\
\text { ppm } \\
\mathrm{mol} \% \\
\mathrm{~mm} \\
\% \mathrm{v} / \mathrm{v} \\
\mathrm{ppm} \\
\% \mathrm{v} / \mathrm{v} \\
\% \mathrm{v} / \mathrm{v} \\
\mu \mathrm{l} \\
\mathrm{ppm} \\
\% \mathrm{v} / \mathrm{v} \\
a_{w} \\
\mathrm{ppm} \\
a_{w} \\
\mathrm{ppm} \\
a_{w} \\
\% \mathrm{v} / \mathrm{v} \\
\mathrm{ppm} \\
a_{w} \\
\mathrm{ppm}\end{array}$ & $\begin{array}{l}\text { Esterification } \\
\text { Hydrolysis } \\
\text { Esterification } \\
\text { Esterification } \\
\text { Esterification } \\
\text { Acidolysis } \\
\text { Esterification } \\
\text { Transesterification } \\
\text { Esterification } \\
\text { Esterification } \\
\text { Alcoholysis } \\
\text { Transesterification } \\
\text { Esterification } \\
\text { Esterification } \\
\text { Interesterification } \\
\text { Interesterification } \\
\text { Hydrolysis } \\
\text { Alcoholysis } \\
\text { Hydrolysis } \\
\text { Esterification } \\
\text { Acidolysis } \\
\text { Esterification }\end{array}$ & $\begin{array}{l}30 \\
45 \\
40 \\
27-55 \\
20-70 \\
40 \\
40 \\
40 \\
10-70 \\
40 \\
40 \\
40 \\
40 \\
30 \\
37 \\
30-60 \\
23 \\
25 \\
37 \\
30 \\
25-45 \\
31.1\end{array}$ & $\begin{array}{l}\text { NA } \\
4.0-9.0 \\
\text { NA } \\
\text { NA } \\
\text { NA } \\
\text { NA } \\
\text { NA } \\
\text { NA } \\
\text { NA } \\
\text { NA } \\
\text { NA } \\
\text { NA } \\
\text { NA } \\
\text { NA } \\
\text { NA } \\
\text { NA } \\
\text { NA } \\
\text { NA } \\
\text { NA } \\
\text { NA } \\
\text { NA } \\
\text { NA }\end{array}$ & $\begin{array}{r}37 \\
38 \\
62 \\
69 \\
85 \\
93 \\
100 \\
107 \\
108 \\
121 \\
125 \\
142 \\
147 \\
149 \\
165 \\
168 \\
170 \\
177 \\
182 \\
186 \\
194 \\
202\end{array}$ \\
\hline
\end{tabular}

NA, Not available

other by-products such as diglycerides (which disturb the polymorphic state of fat crystals by softening them, ${ }^{16}$ and therefore produce lower quality additives for confectionary products) requires accurate control of the water content in the reaction medium, and such control also leads to more predictable rates of deactivation of the lipase. ${ }^{17} \mathrm{~A}$ feedback control system (with a hygrometer as sensor) coupled with two regulatory control systems (a feedforward/feedback controller with an on-line enzyme activity estimator and a state estimator based on a Kalman filter) was successfully employed ${ }^{18}$ to master the glyceride composition of fats and oils during continuous interesterification. Numerical models which deal with the dynamic behavior of the water concentration are important when evaluating dynamic characteristics, optimizing outlet conversion, and designing control systems. If such models are capable of providing good representations of dynamic behaviors, then they will serve as useful aids in the development of more accurate and selective reaction systems involving immobilized lipase reactors.

Although a great many lipase-catalyzed reactions studied in the past were carried out in emulsion systems, there is an impetus to avoid use of emulsifiers because of several drawbacks for industrial processes, viz. 1) emulsions are sometimes difficult to break, and 2) replacing oil-bulk water interfaces by bound water-oil or bound water-organic solvent interfaces leads to lower deactivation rates. This statement is backed up by a careful inspection of Table 1 , in which only few references exist encompassing the use of immobilized lipases in emulsion systems.

The discovery that lipases successfully catalyze reactions under almost anhydrous conditions in organic media (i.e., when water is eliminated except for an essential thin layer of water more or less tightly bound to the enzyme and required for maintenance of its integrity) has made the range of possible chemical reactions widen far beyond hydrolysis. However, an overview of Table $I$ indicates an increasing trend for the use of solvent-free systems to accomplish reactions catalyzed by immobilized lipases, although it is known that use of solvents lowers the viscosity of the reaction system and thus facilitates such reactions in terms of mechanical processing. It is a fact that when reactions are carried out in a solvent, the reaction product(s) has to be cleaned and deodorized for safety of human use, and these processes are likely to destroy fine flavors, as in the case of lipolyzed butterfat. However, use of apolar (hydrophobic) solvents to liquefy substrates retards deactivation of the lipase, because most water is kept away from the enzyme folded structure (except for bound water needed for maintaining the integrity of the lipase's globular structure), thus promoting a more rigid lipase conformation. When the substrates for lipase-catalyzed reactions are solid at room temperature (e.g., butterfat and tallow), the absence of solvents to liquefy them by solubilization can be replaced by increasing the temperature (to values usually ranging from 30 to $60^{\circ} \mathrm{C}$ ) to liquefy them by melting, and this increase in temperature is expected to accelerate deactivation of the immobilized lipase. From these arguments, it is obvious that decision of whether to select a solvent to carry out lipasecatalyzed reactions must carefully take several considerations into account and balance process and product constraints.

Despite all possible applications of immobilized lipases, it seems that hydrolysis and interesterification reactions (i.e., the most ancient and classical applications of lipases) are still the ones for which lipase reactors are most commonly employed; in addition, although applications of li- 
pases for low-molecular-weight acid and alcohol handling have been reported, preferred substrates are still long-chain organic compounds (see Table 1).

Search for lower operating costs (which depend heavily on the enzyme cost itself) has led, in the last few years, to an increase in the use of lipase reactors working on a continuous fashion although, on a laboratory scale, BSTRs are still the most appropriate choice for testing and comparing results obtained with other tentative configurations. A comparative assessment of the merits of an HFMR operated continuously for the controlled accelerated lipolysis of butterfat relative to the conventional free enzyme process ${ }^{19}$ indicates that the membrane reactor provides a very attractive alternative to traditional batch reactor technology. The costs arising from addition of emulsifier, homogenization and stirring of butterfat, and thermal processing of the lipolyzed butterfat are nil for the immobilized lipase, whereas the costs resulting from addition of glycerol, and use of ethanol and hexane during the cleaning and regeneration step (when spent absorbed enzyme is removed and replaced with fresh lipase) are nil for the traditional process. The incremental costs associated with the immobilized lipase continuous process are more than 20 times smaller than the ones associated with the traditional one, arising primarily from the cost of the relatively large amount of lipase required by the latter process ${ }^{20}$; therefore, the use of lipase in an immobilized form leads to a much greater productivity. A major advantage here results from using adsorption to immobilize the lipase, because its low cost and feasibility of regeneration of the lipase activity (and consequent reuse of the support) provide clear economic benefits to the reactor technology in question.

\section{Final remarks}

The increasing availability of lipases from genetically engineered microbial sources, their intrinsic capacity to act as catalysts in both macro- and microaqueous systems coupled with their activation by oil-water interfaces, and the recent advances in the knowledge of structure-function relationships for their enzymes have contributed to a situation where lipases have generated the interest of a great number of both fundamental and applied researchers. However, although their range of potential features is very wide, their use in industrial scale is not yet very common, mainly because of the high cost normally associated with them or with supports used in immobilization procedures which are not reusable. Hence, major efforts in the near future should focus both on techniques on the genetic expression side to increase the amounts and improve the stability and activity of lipases, and on techniques on the material science side to improve the mechanical, diffusional, kinetic, and regeneration characteristics of the support.

It is expected that in the near future, the interchange of experiences and knowledge between crystallographers, biochemists, geneticists, and enzyme kineticists on the one hand, and food, chemical, and biochemical engineers on the other will create synergisms by allowing the former to learn what are the practical aims and constraints associated with industrial applications of lipases (and thus be able to design lipases to address these issues), and by allowing the latter to learn how advantage can be taken from the structural knowledge of lipases and their metabolic genesis to better design media, processes, and products in terms of biochemical, technical, and economic feasibility (and concomitantly optimize them in terms of volumetric efficiency). It is hoped that the present report will help achieve this goal.

\section{Abbreviations}

ADCPG alkylamine derivative of controlled pore

$\begin{array}{ll}\text { AHA } & \text { alass } \\ \text { aminohexanoic acid }\end{array}$

AMDG

AOT-RM alkylamine derivative of glass

reverse micelles

BFT bleachable fancy tallow

BIU batch interesterification unit

BSP biomass support particles

BSTR batch stirred-tank reactor

C carrier

cf covalent forces

CSTR continuous flow stirred-tank reactor

CWD cell wall debris

DDA 1,12-diaminododecane

DHA C22:6 $\omega 3$ (cis-4,7,10,13,16,19 docosahexanoic acid)

E enzyme

EDA ethylene diamine

ENT cross-linkable resin prepolymer containing polyethylene glycol

ENTP cross-linkable resin prepolymer containing polypropylene glycol

EPA C20:5 1 3(cis-5,8,11,14,17 eicosapentaenoic acid)

$\begin{array}{ll}\text { EPSPS } & \begin{array}{l}\text { epoxypropylsilanized PartiSphere-5 } \\ \text { fluidized-bed reactor }\end{array} \\ \text { FTR } & \text { flow-through membrane reactor } \\ \text { FSMR } & \begin{array}{l}\text { flat-sheet membrane reactor } \\ \text { glutaraldehyde }\end{array} \\ \text { ga } & \text { high density polyethylene } \\ \text { HDPE } & \text { high erucid acid rapeseed oil } \\ \text { HEAR } & \text { hollow-fiber membrane reactor } \\ \text { HFMR } & \text { hexamethylenediamine } \\ \text { HMDA } & \text { ionic forces } \\ \text { if } & \text { packed-bed reactor } \\ \text { PBR } & \text { polyethylene glycol } \\ \text { peg } & \text { polytetrafluoroethylene } \\ \text { PTFE } & \text { polyunsaturated fatty acids } \\ \text { PUFA } & \text { polyvinylchloride } \\ \text { PVC } & \text { recycle dialysis reversed micellar reactor } \\ \text { RDRMR } & \text { tresyl-activated silica } \\ \text { TAS } & \text { van der Waals forces } \\ \text { vdW } & \end{array}$

\section{Acknowledgments}

The authors are grateful to JNICT (Portugal) and Institut CANDIA (France) for fellowship support and PRAXIS XXI (Portugal, Project Extractive Biocatalysis) for financial support. 


\section{References}

1. Sarda, L. and Desnuelle, P. Biochim. Biophys. Acta 1958, 30, 513-521

2. Verger, R. and Haas, G. H. Ann. Rev. Biophys. Bioeng. 1976, 5, 77-117

3. Antonian, E. Lipids 1988, 23, 1101-1106

4. Winkler, F. K., D'Arcy, A. and Hunziker, W. Nature 1990, 343, $771-774$

5. van Tilbeurg, H., Sarda, L., Verger, R. and Cambillau, C. Nature 1992, 359, 159-162

6. van Tilbeurg, H., Egloff, M. P., Martinez, C., Rugani, N., Verger, R. and Cambillau, C. Nature 1993, 362, 814-820

7. Malcata, F. X., Garcia, H. S., Hill, C. G., Jr. and Amundson, C. H. Biotechnol. Bioeng. 1992, 39, 647-657

8. Dillman, W. J. and Miller, I. F. J. Coll. Interf. Sci. 1973, 44, 221

9. Patton. J. S. and Andersson, L. FEBS Lett. 1978, 86, 179

10. Brockman, H. L., Law, J. H. and Kézdy, F. J. J. Biol. Chem. 1973, 245, 4965-4970

11. Malcata, F. X., Hill, C. G., Jr. and Amundson, C. H. Biotechnol. Bioeng. 1991, 38, 853-868

12. Schwimmer, S. Source Book of Food Enzymology AVI Publishing, 1981, 205.437

13. Bailey, J. E. and Ollis, D. F. Biochemical Engineering Fundamentals McGraw-Hill, New York, 1986, 133-140

14. Whitaker, J. R. Principles of Enzymology for the Food Sciences Marcel Dekker, New York, 1972, 342

15. Pilone, M. S., Pollegioni, L. and Buto, S. (415); Prazeres, D. M. F., Garcia, F. A. P. and Cabral, J. M. S. (445); In: Studies in Organic Chemistry, vol. 47: Stability and Stabilization of Enzymes, (van den Tweel, W. J. J., Harder, A. and Buitelaar, R. M., eds.). Elsevier Science Publishers B. V., Amsterdam, 1993

16. Kyotani, S., Nakashima, T., Izumoto, E. and Fukuda, H. J. Ferment. Bioeng. 1991, 71, 286-288

17. Izumoto, E., Fukuda, H., Nojima, Y. and Nakanishi, E. Chem. Eng. Sci. 1992, 47, 2351-2356

18. Izumoto, E., Fukuda, H. and Nakanishi, E. Int. Chem. Eng. 1992, 32, 570-577

19. Malcata, F. X. and Hill, C. G., Jr. In: Third International Conference on Effective Membrane Processes-New Perspectives (Paterson, R., ed.). Mechanical Engineering Publications Ltd., 1993, $107-122$

20. Malcata, F, X. and Hill, C. G., Jr. Ann. NY Acad. Sci. 1995, 750, 401-407

21. Baillargeon, M. W. and Sonnet, P. H. Ann. NY Acad. Sci. 1988, 542, 244-249

22. Bevinakatti, H. S. and Banerji, A. A. Biotechnol. Lett. 1988, 10, 397-398

23. Brady, C., Metcalfe, L., Slaboszewski, D. and Frank, D. J. Amer. Oil Chem. Soc. 1988, 65, 917-921

24. Graille, J., Pina, M. and Montet D. Oléagineux 1988, 43, 181-187

25. Higuchi, K. and Hirata, H. J. Jpn. Oil Chem. Soc., 1988, 37, 599-605

26. Hills, M. J., Kiewitt, I. and Mukherjee, K. D. Biochem. Soc. Trans. 1988,478

27. Ison, A. P., Dunnill, P. and Lilly, M. D. Enzyme Microb. Technol. $1988,10,47-51$

28. Jensen, B. H., Galluzzo, D. R. and Jensen, R. G. J. Amer. Oil Chem. Soc. 1988, 65, 905-910

29. Kaimal, T. N. B. and Saroja, M. Biotechnol. Lett. 1988, 10, 337340

30. Kalo, P., Perttila, M., Kemppinen, A. and Antila, M. Meijeritietcellinen Aikakauskirja 1988, 46, 36-47

31. Kemppinen, A., Kalo, P. and Antila, M. Meijeritieteellinen Aikakauskirja 1988, 46, 48-55

32. Kyotani, S., Fukuda, H., Morikawa, II. and Yamane, T. J. Ferment. Technol. 1988, 66, 71-83

33. Miller, C., Austin, H., Posorske, L. and Gonzalez, J. J. Amer. Oil Chem. Soc. 1988, 65, 927-931

34. Muderhwa, J., Pina, M. and Graille, J. Oléagineux 1988, 43, 385392

35. Nishio, 'T., 'lakahashi, K., Tsuzuki, T., Yoshimoto, T., Kodera, Y., Matsushima, A., Saito, Y. and Inada, Y. J. Biotechnol. 1988, 8, $39-44$
36. Norin, M., Boutelje, J., Holmberg, E. and Hult, K. Appl. Microbiol Biotechnol. 1988, 28, 527-530

37. Omar, I. C., Nishio, N. and Nagai, S. Biotechnol. Lett. 1988, 10, 799-804

38. Omar, I. C., Saeki, H., Nishio, N. and Nagai, S. Agric. Biol. Chem. 1988, 52, 99-105

39. Posorske, L. H., LeFebvre, G. K., Miller, C. A., Hansen, T. T. and Glenvig, B. L. J. Amer. Oil Chem. Soc. 1988, 65, 922-926

40. Pronk, W., Kerkhof, P. J. A. M., van Helden, C. and van't Riet, K. Biotechnol. Bioeng. 1988, 32, 512-518

41. Thomas, K. C., Magnuson, B., McCurdy, A. R. and GrootWassink, J. W. D. Can. Inst. Food Sci. Technol. J. 1988, 21, 167-173

42. Wang, C. S., Hartsuck, J. A and Downs, D. Biochemistry 1988, 27, $4834-4840$

43. Wang, Y. J., Sheu, J. Y., Wang, F. F. and Shaw, J. F. Biotechnol Bioeng. 1988, 31, 628-633

44. Williams, R. E., Armstrong, D. W., Murray, W. D. and Welsh, F. W. Ann. NY Acad. Sci. 1988, 542, 406-412

45. Bjørkling, F., Godtfredsen, S. E. and Kirk, O. J. Chem. Soc. Chem. Commun. 1989, 14, 934-935

46. Haalck, L. and Spener, F. DECHEMA Biotechnology Conferences 3: VCH Verlagsgesellschaft 1989, 113-116

47. Haraldsson, G. G. In: Proceedings of the 15th Scandinavian Symposium on Lipids, $1989,245-248$

48. Haraldsson, G. G., Hoskuldsson, P. A., Sigurdsson, S. T., Thorsteinsson, F. and Gudbjamason, S. Tetrahedron Lett. 1989, 30, $1671-1674$

49. Holmberg, E., Szmulik, P., Norin, T. and Hult, K. Biocatalysis $1989,2,217-223$

50. Kadyrova, Z. Kh., Abdurakhimov, S. A. and Khalniyazov, K. K. Chem. Nat. Compd. 1989, 19, 411-413

51. Kaimal, T. N. B. and Saroja, M. J. Oil Technol. Assoc. India 1989, 21, 2-10

52. Kaimal, T. N. B. and Saroja, M. Biotechnol. Lett. 1989, 11, 31-36

53. Kalo, P., Huotari, H. and Antila, M. Fat Sci. Technol. 1989, 91, 276-280

54. Kalo, P., Huotari, H. and Antila, M. Meijeritieteellinen Aikakauskirja 1989, 47, 29-38

55. Kalo, P., Huotari, H., Kemppinen, A. and Antila, M. In: Proceedings of the Congrès International "Chevreul" pour L'étude des Corps Gras-Premier Congrès Eurolipid, 1989, 256-263

56. Kang, S. T. and Rhee, J. S. Biotechnol. Lett. 1989, 11, 37-42

57. Kang, S. T. and Rhee, J. S. Biotechnol. Bioeng. 1989, 33, 1469 1476

58. Kurashige, J., Matsuzaki, N. and Makabe, K. J. Dispersion Sci. Technol. 1989, 10, 531-559

59. Langholz, P., Andersen, P., Forskov, T. and Schmidtsdorff, W. $J$. Amer. Oil Chem. Soc. 1989, 66, 1120-1123

60. Muderhwa, J. M., Pina, M. and Graille, J. Revue Françuise des Corps Gras 1989, 36, 11-19

61. Muderhwa, J. M., Pina, M., Montet, D., Feuillard, P. and Graille, J. Oléagineux $1989,44,35-43$

62. Omar, 1. C., Saeki, H., Nishio, N. and Nagai, S. Biotechnol. Lett. $1989,11,161-166$

63. Osterberg, E., Blomstrom, A. C. and Holmberg, K. J. Amer. Oil Chem. Soc. 1989, 66, 1330-1333

64. Rucka, M., Turkiewicz, B., Tomaszewska, M. and Chlubek, N. Biotechnol. Lett. 1989, 11, 167-172

65. Schuch, R. and Mukherjee, K. D. Appl. Microbiol. Biotechnol. $1989,30,332-336$

66. Stark, M. B. and Holmberg, K. Biotechnol. Bioeng. 1989, 34, 942950

67. Bloomer, S., Adlercreutz, P. and Mattiasson, B. J. Amer. Oil Chem. Soc. 1990, 67, 519-524

68. Chang, M. K., Abraham, G. and John, V. T. J. Amer, Oil Chem. Soc. $1990,67,832-834$

69. Chulalaksananukul, W., Condoret, J. S., Delorme, P. and Willemot, R. M. FEBS Lett. 1990, 276, 181-184

70. Ergan, F., Lamare, S. and Trani, M. Ann. NY Acad. Sci. 1990, 613, $37-44$

71. Goldberg, M., Thomas, D. and Legoy, M. D. Enzyme Microb. Technol. 1990, 12, 976-981

72. Goldberg, M., Thomas, D. and Legoy, M. D. Eur. J. Biochem. $1990,190,603-609$ 
73. Gray, C. J., Narang, J. S. and Barker, S. A. Enzyme Microb. Technol. $1990,12,800-807$

74. Han, D., Walde, P. and Luisi, P. L. Biocatalysis 1990, 4, 153-161

75. Hills, M. J., Kiewitt, I. and Mukherjee, K. D. J. Amer. Oil Chem. Soc, $1990,67,561-564$

76. Holmberg, E. and Hult, K. Biocatalysis 1990, 3, 243-251

77. Ison, A. P., Dunnill, P., Lilly, M. D., Macrae, A. R. and Smith, C. G. Biocatalysis 1990, 3, 329-342

78. Kalo, P., Harjunpaa, V. and Kemppinen, A. In: Proceedings of the XXIII International Dairy Congress, Montreal, 1990, 351

79. Kalo, P., Huotari, H. and Antila, M. Milchwiss. 1990, 45, 281-285

80. Kéry, V., Haplová, J., Tihlárik, K. and Schmidt, S. J. Chem. Tech. Biotechnol. 1990, 48, 201-207

81. Khurana, A. L. and Ho, C. T. J. Liq. Chromat. 1990, 13, 715-725

82. Knez, Z., Leitgeb, M., Zavrsnik, D. and Lavric, B. Fat Sci. Technol. 1990, 92, 169-172

83. Kolisis, F. N., Valis, T. P. and Xenakis, A. Ann. NY Acad. Sci. $1990,613,674-680$

84. Langrand, G., Rondot, N., Triantaphylides, C. and Baratti, J. Biotechnol. Lett. 1990, 12, 581-586

85. Leitgeb, M. and Knez, Z. J. Amer. Oil Chem. Soc. 1990, 67, 775-778

86. Linko, Y. Y., Koivisto, U. M. and Kautola, H. Ann NY Acad. Sci. 1990, 613, 691-696

87. Linko, Y. Y. and Yu, H. C. Ann. NY Acad. Sci. 1990, 613, 493-496

88 Miller, D. A., Blanch, H. W. and Prausnitz, J. M. Ann. NY Acad. Sci. $1990,613,534-537$

89. Otero, C., Pastor, E., Fernández, V. M. and Ballesteros, A. Appl. Biochem. Biotechnol. 1990, 23, 237-247

90. Otero, C., Pastor, E., Rua, M. L. and Ballesteros, A. Ann. NY Acad. Sci. 1990, 613, 523-528

91. van der Padt, A., Edema, M. J., Sewalt, J. J. W. and van't Riet, K. J. Amer. Oil Chem. Soc. 1990, 67, 347-352

92. Patel, R. N., Howell, J. M., Banerjee, A., Fortney, K. F. and Szarka, L. J. Ann. NY Acad. Sci. 1990, 613, 415-424

93. Reyes, H. R., Hill, C. G., Jr. and Amundson, C. H. In: Proceedings of the AIChE Annual Meetings, Chicago, ILNovember 1990, Fat and Oil Fractionation and Modification in the Food Industry.

94. Rucka, M. and Turkiewicz, B. Enzyme Microb. Technol. 1990, 12, $52-55$

95. Rucka, M., Turkiewicz, B. and Zuk, J. S. J. Amer. Oil Chem. Soc. $1990,67,887-889$

96. Shaw, J. F., Chang, R. C., Wang, F. F. and Wang, Y. J. Biotechnol. Bioeng. 1990, 35, 132-137

97. Svensson, I., Adlercreutz, P. and Mattiasson, B. Appl. Microbiol. Biotechnol. 1990, 33, 255-258

98. Taylor, F. and O'Brien, D. J. Developments in Industrial Microbiology 1990, 31, 59-62

99. Welsh, F. W., Williams, R. E. and Dawson, K. H. J. Food Sci. $1990,55,1679-1682$

100. Yamane, T., Ichiryu, T., Nagata, M., Ueno, A. and Shimizu, S. Biotechnol. Bioeng. 1990, 36, 1063-1069

101. Dias, S. F., Vilas-Boas, L., Cabral, J. M. S. and Fonseca, M. M. R. Biocatalysis 1991, 5, 21-34

102. Gancet, C. Heterogeneous Catalysis and Fine Chemicals II. Elsevier Science Publishers B.V., Amsterdam, 1991, 93-104

103. Garcia, H. S., Amundson, C. H. and Hill, C. G. J. Food Sci. 1991, 56, 1233-1237

104. Haraldsson, G. G. and Almarsson, O. Acta Chemica Scandinavian $1991,45,723-730$

105. Kalo, P. and Harjunpaa, V. In: Proceedings of the LIPIDFORUMScandinavian Forum for Lipid Research and Technology, 16th Scandinavian Symposium on Lipids, Norway, 100-103

106. Kim, S. M. and Rhee, J. S. J. Amer. Oil Chem. Soc. 1991, 68, 499-503

107. Kyotani, S., Nakashima, T., Izumoto, E. and Fukuda, H. J. Ferment. Bioeng. 1991, 71, 286-288

108. Manjón, A., Iborra, J. L. and Arocas, A. Biotechnol. Lett. 1991. 13, 339-344

109. McNeill, G. P., Shimizu, S. and Yamane, T. J. Amer. Oil Chem. Soc. 1991, 68, 1-5

110. Miller, D. A., Prausnitz, J. M. and Blanch, H. W. Enzyme Microb. Technol. 1991, 13, 98-103

111. van der Padt, A. and van't Riet, $\mathrm{K}$. In: Chromatographic and
Membrane Processes in Biotechnology (C. A. Costa and J. S. Cabral, eds.). Kluwer, Dordrecht, 1991, 443-448

112. Sridhar, R., Lakshminarayana, G. and Kaimal, T. N. B. J. Agric. Food Chem. 1991, 39, 2069-2071

113. Sridhar, R., Lakshminarayana, G. and Kaimal, T. N. B. J. Amer Oil Chem. Soc. 1991, 68, 726-730

114. Taylor, F. and Craig, J. C. Enzyme Microb. Technol. 1991, 13, 956-959

115. Trani, M., Ergan, F. and André, G. J. Amer. Oil Chem. Soc. 1991 , 68, 20-22

116. Tsai, S. W. and Chiang, C. L. Biotechnol. Bioeng. 1991, 38, 206211

117. Wang, Y. and Gordon, M. H. J. Amer. Oil Chem. Soc. 1991, 68, $588-590$

118. Berger, M. and Schneider, M. P. J. Amer. Oil Chem. Soc. 1992, 69, $961-965$

119. Berger, M., Laumen, K. and Schneider, M. P. J. Amer. Oil Chem Soc. $1992,69,955-960$

120. Cao, S. G., Feng, Y., Liu, Z. B., Ding, Z. T. and Cheng, Y. H. Appl. Biochem. Biotechnol. 1992, 32, 7-13

121. Cao, S. G., Liu, Z. B., Feng, Y., Ma, L., Ding, Z. T. and Cheng, Y. H. Appl. Biochem. Biotechnol. 1992, 32, 1-6

122. Chen, J. P. and McGill, S. D. Food Biotechnol. 1992, 6, 1-18

123. Chen, J. P. and Yang, B. J. Food Sci. 1992, 57, 781-782

124. Chiang, C. L. and Tsai, S. W. J. Chem. Tech. Biotechnol. 1992, 54, 249-255

125. Chulalaksananukul, W., Condoret, J. S. and Combes, D. Enzyme Microb. Technol. 1992, 14, 293-298

126. Chong, C. N., Hoh, Y. M. and Wang, C. W. J. Amer. Oil Chem. Soc. 1992, 69, 137-140

127. Dewettinck, K., De Greyt, W. and Huyghebaert, A. Med. Fac. Landbouww. Univ. Gent 1992, 57, 1905-1907

128. Ducret, A., Pina, M., Montet, D. and Graille, J. Biotechnol Lett. 1992, 14, 185-188

129. Forssell, P., Kervinen, R., Lappi, M., Linko, P., Suortti, T. and Poutanen, K. J. Amer. Oil Chem. Soc. 1992, 69, 126-129

130. Garcia, H. S., Malcata, F. X., Hill, C. G. and Amundson, C. H. Enzyme Microb. Technol. 1992, 14, 535-545

131. Ghoshray, S. and Bhattacharya, D, K. J. Amer. Oil Chem. Soc $1992,69,85-88$

132. Haalck, L., Hedrich, H. C., Hassink, J. and Spener, F. In: Proceedings of Fundamentals of Biocatalysis in Non-Conventional Media, Elsevier Science Publishers B.V., Amsterdam, 1992

133. Haraldsson, G. G., Gudmundsson, B. O. and Almarsson, O. In: Proceedings of the 83rd AOCS Annual Meeting, Toronto, 1992

134. Hayes, D. G. and Gulari, E. Biotechnol. Bioeng. 1992, 40, 110-118

135. Hertzberg, S., Kvittingen, L., Anthonsen, T. and Skjak-Braek, G. Enzyme Microb. Technol. 1992, 14, 42-47

136. Kirk, O., Bjørkling, F., Godtfredsen. S. E. and Larsen, T. O. Biocatalysis 1992, 6, 127-134

137. Lakshmanan, A., Rao, P. V., Jayaraman, K. and Lakshmanan, C. M. Biotechnol. Technol. 1992, 6, 169-172

138. Malcata, F. X., Garcia, H. S., Hill, C. G. and Amundson, C. H. Biotechnol. Bioeng. 1992, 39, 647-657

139. Malcata, F. X., Hill, C. G. and Amundson, C. H. Biotechnol. Bioeng. 1992, 39, 984-1001

140. Malcata, F. X., Hill, C. G. and Amundson, C. H. Biotechnol. Bioeng. 1992, 39, 1002-1012

141. Malcata, F. X., Hill, C. G. and Amundson, C. H. Biotechnol. Bioeng. 1992, 39, 1097-1111

142. Nakashima, T., Kyotani, S., Izumoto, E. and Fukuda, H. In: Proceedings of Asia-Pacific Biochemical Engineering Conference 1992, 115-117

143. van der Padt, A., Sewalt, J. J. W., Ágoston, S. M. I. and Van't Riet, K. Enzyme Microb. Technol. 1992, 14, 805-812

144. Parvaresh, F., Robert, H., Thomas, D. and Legoy, M. D. Biotechnol. Bioeng. 1992, 39, 467-473

145. Pecnik, S. and Knez, Z. J. Amer. Oil Chem. Soc. 1992, 69, 261-265

146. Prazeres, D. M. F., Lemos, F. and Cabral, J. M. S. In: Proceedings of the NATO Advanced Study Institute on Use of Computer and Informatic Systems in Bioprocess Engineering, Portugal, 1992

147. Rizzi, M., Stylkos, P., Riek, A. and Reuss, M. Enzyme Microb. Technol. 1992, 14, 709-714 
148. Taylor, F., Kurantz, M. J. and Craig, J. C. J. Amer. Oil Chem. Soc. $1992,69,591-594$

149. Valivety, R. H., Halling, P. J., Peilow, A. D. and Macrac, A. R. Biochim. Biophys. Acta 1992, 1122, 143-146

150. Vermue, M. H., Tramper, J., Jong, J. P. J. and Oostrom, W. H. M. Enzyme Microb. Technol. 1992, 14, 649-655

151. Frykman, H., Ohrner, N., Norin, T. and Hult, K. Tetrahedron Lett. 1993, 34, 1367-1370

152. Gandhi, N. N., Sawant, S. B. and Joshi, J. B. Biotechnol. Bioeng., in press

153. Hashimoto, Y. In: Industrial Applications of Immobilized Biocatalysts (Tanaka, A., Tosa, T. and Kobayashi, T., eds.). Marcel Dekker, New York, 1993, 337-352

154. Kalo, P. and Kemppinen, A. J. Amer. Oil Chem. Soc. 1993, 70, 1209-1217

155. Kalo, P., Rinne, J., Huotari, H. and Antila, M. Fat Sci. Technol. $1993,95,58-62$

156. Kemppinen, A. and Kalo, P. J. Amer. Oil Chem. Soc. 1993, 70, 1203-1207

157. Li, Z.-Y. and Ward, O. P. I. Amer. Oil Chem. Soc. 1993, 70, 745-748

158. Malcata, F. X. and Hill, C. G. In: Proceedings of the 3rd International Conference on Effective Membrane Processes: New Perspectives, UK, 1993

159. Malcata, F. X., Hill, C. G. and Amundson, C. H. Biocatalysis 1993, 7, 177-219

160. Marangoni, A. G., McCurdy, R. D. and Brown, E. D. J. Amer. Oil Chem. Soc. 1993, 70, 737-744

161. Mustranta, A., Forssell, P. and Poutanen, K. Enzyme Microb. Technol. 1993, 15, 133-139

162. Stenning, R. A., Needs, E. C., Brooker, B. E. and Vulfson, E. N. Biotechnol. 1993, 11, 1299-1301

163. Christensen, T. C. and Hølmer, G. Milchwiss. 1993, 48, 543-548

164. Li, Z.-Y. and Ward, O. P. Biotechnol. Lett. 1993, 15, 185-188

165. Mojovic, L., Siler-Marinkovic, S., Kukic, G. and Vunjak-Novakovic, G. Enzyme Microb. Technol. 1993, 15, 438-443

166. Kurashige, J., Matsuzaki, N. and Takahashi, H. J. Amer. Oil Chem. Soc. 1993, 70, 849-852

167. Foglia, T. A., Petruso, K. and Feairheller, S. H. J. Amer. Oil Chem. Soc. 1993, 70, 281-285

168. Cho, S.-W. and Rhee, J. S. Biotechnol. Bioeng. 1993, 41, 204-210

169. Forssell, P., Parovuori, P., Linko, P. and Poutanen, K. J. Amer. Oil Chem. Soc. 1993, 70, 1105-1109

170. Hayes, D. G. and Kleiman, R. J. Amer. Oil Chem. Soc. 1993, 70, 1121-1127

171. Mukesh, D., Banerji, A. A., Newadkar, R. and Bevinakatti, H. S. Biocatalysis 1993, 8, 191-199

172. Yamane, T., Suzuki, T. and Hoshino, T. J. Amer. Oil Chem. Soc. $1993,70,1285-1287$

173. Malcata, F. X., Hill, C. G., Jr. and Amundson, C. H. Biocatalysis $1993,8,201-228$

174. Haraldsson, G. G., Gudinundsson, B. O. and Almarsson, O. Tetrahedron Lett. 1993, 34, 5791-5794

175. Giorno, L., Molinari, R., Drioli, E., Bianchi, D. and Cesti, P. Biotechnol. Bioeng., in press

176. Kierkels, J. G. T., Vleugels, L. F. W., Geladé, E. T. F., Vermeulen, D. P., Kamphuis, J., Wandrey, C. and van den Tweel, W. J. J. Enzyme Microb. Technol. 1994, 16, 513-521

177. Millqvist, A., Tian, L. and Adlercreutz, P. In: Abstract Book of the Closing Meeting of the EC Bridge Lipase T-Project, Bendor Island, Bandol, France, Sept. 14-17, 1994, 110
178. Norin, M., Haeffner, F., Hult, K. and Edholm, O. Biophysical $J$ 1994, 67, 548-559

179. Sarney, D. B., Fregapane, G. and Vulfson, E. N. J. Amer. Oil Chem. Soc. 1994, 71, 93-96

180. Ison, A. P., MacRae, A. R., Smith, C. G. and Bosley, J. Biotechnol. Bioeng. 1994, 43, 122-130

181. Bystrom, C. E. and Hartel, R. W. Lebensm. Wiss.u. Technol. 1994 27, $142-150$

182. Pencreac'h, G., Marquez, B. and Baratti, J. C. In: Abstract Book of the Closing Meeting of the EC Bridge Lipase T-Project, Bendor Island, Bandol, France, Sept. 14-17, 1994, 71

183. Tanaka, Y., Hirano, J. and Funada, T. J. Amer. Oil Chem. Soc. 1994, 71, 331-334

184. Kodera, Y., Nishimura, H., Matsushima, A., Hiroto, M. and Inada Y. J. Amer. Oil Chem. Soc. 1994, 71, 335-342

185. Kosugi, Y., Kunieda, T. and Azuma, N. J. Amer. Oil Chem. Soc. $1994,71,445-448$

186. Shaw, J.-F. and Lo, S. J. Amer. Oil Chem. Soc. 1994, 71, 715-719

187. Multzsch, R., Lokotsch, W., Steffen, B., Lang, S., Metzger, J. O. Schäefer, H. J., Warwcl, S. and Wagner, F. J. Amer. Oil Chem. Soc. 1994, 71, 721-725

188. Maehr, H., Zenchoff, G. and Coffen, D. L. J. Amer. Oil Chem. Soc. 1994, 71, 463-467

189. Kimoto, H., Endo, Y. and Fujimoto, K. J. Amer. Oil Chem. Soc. $1994,71,469-473$

190. Haas, M. J., Scott, K., Jun, W. and Janssen, G. J. Amer. Oil Chem Soc. 1994, 71, 483-490

191. Syed Rahmatullah, M. S. K., Shukla, V. K. S. and Mukherjee, K. D. J. Amer. Oil Chem. Soc. 1994, 71, 563-567

192. Syed Rahmatullah, M. S. K., Shukla, V. K. S. and Mukherjee, K. D. J. Amer. Oil Chem. Soc. 1994, 71, 569-573

193. Claon, P. A. and Akoh, C. C. J. Amer. Oil Chem. Soc. 1994, 71, 575-578

194. Gioielli, L. A., Pitombo, R. N. M., Vitolo, M., Baruffaldi, R., Oliveira, M. N. and Augusto, M. S. J. Amer. Oil Chem. Soc. 1994, 71, 579-582

195. Singh, C. P., Shah, D. O. and Holmberg, K. J. Amer, Oil Chem. Soc. 1994, 71, 583-587

196. Yamane, T., Kang, S. T., Kawahara, K. and Koizumi, Y. J. Amer. Oil Chem. Soc. 1994, 71, 339-342

197. Oba, T. and Witholt, B. J. Dairy Sci. 1994, 77, 1790-1797

198. Reyes, H. R. and Hill, C. G., Jr. Biotechnol. Bioeng. 1994, 43, $171-182$

199. Akoh, C. C. and Mutua, L. N. Enzyme Microb. Technol. 1994, 16, 115-119

200. Virto, M. D., Agud, I., Montero, S., Blanco, A., Solozabal, R., Lascaray, J. M., Llama, M. J., Serra, J. L., Carlos Landeta, L. and Renobales, M. Enzyme Microb. Technol. 1994, 16, 61-65

201. Millqvist, A., Adlercreutz, P. and Matiasson, B. Enzyme Microb. Technol. 1994, 16, 1042-1047

202. Martins, J. F., Carvalho, I. B., Sampaio, T. C. and Barreirns, S Enzyme Microb. Technol. 1994, 16, 785-790

203. Stevenson, D. E., Stanley, R. A. and Furneaux, R. H. Enzyme Microb. Technol. 1994, 16, 478-484

204. Robinson, G. K., Alston, M. J., Knowles, C. J., Cheetham, P. S. J. and Motion, K. R. Enzyme Microb. Technol. 1994, 16, 855-863

205. Claon, P. A. and Akoh, C. C. Enzyme Microb. Technol. 1994, 16, 835-838

206. Paiva, A. L. and Malcata, F. X. Biotechnol. Technol. 1994, 8, 629634 